\title{
Dietary Supplements-For Whom? The Current State of Knowledge about the Health Effects of Selected Supplement Use
}

\author{
Regina Ewa Wierzejska
}

Citation: Wierzejska, R.E. Dietary Supplements-For Whom? The

Current State of Knowledge about the Health Effects of Selected Supplement Use. Int. J. Environ. Res. Public Health 2021, 18, 8897. https://doi.org/ 10.3390/ijerph18178897

Academic Editor: Paul B. Tchounwou

Received: 15 July 2021

Accepted: 21 August 2021

Published: 24 August 2021

Publisher's Note: MDPI stays neutral with regard to jurisdictional claims in published maps and institutional affiliations.

Copyright: (C) 2021 by the author. Licensee MDPI, Basel, Switzerland. This article is an open access article distributed under the terms and conditions of the Creative Commons Attribution (CC BY) license (https:// creativecommons.org/licenses/by/ $4.0 /)$.
Department of Nutrition and Nutritional Value of Food, National Institute of Public Health NIH-National Research Institute, Chocimska St. 24, 00-791 Warsaw, Poland; rwierzejska@pzh.gov.pl

\begin{abstract}
Dietary supplements are products containing nutrients sold in various medicinal forms, and their widespread use may stem from the conviction that a preparation that looks like a drug must have therapeutic properties. The aim of this scoping review is to present what is known about the effects of using selected dietary supplements in the context of chronic diseases, as well as the risks associated with their use. The literature shows that the taking of vitamin and mineral supplements by healthy people neither lowers their risk of cardiovascular diseases nor prevents the development of malignancies. Many scientific societies recognize that omega- 3 fatty acids lower blood triglycerides, but whether taking them prevents heart disease is less clear-cut. Taking weight loss supplements is not an effective method of fighting obesity. Often, some supplements are increasingly sold illegally, which is then also associated with the higher risk that they may be adulterated with banned substances, thus making them even more dangerous and potentially life-threatening. Supplements are necessary in cases of nutrient deficiency; however, even though prescription is not required, their use should be recommended and monitored by a physician.
\end{abstract}

Keywords: dietary supplements; legal regulations; health; safety

\section{Introduction}

In accordance with the European Union law, as well as the United States law, dietary supplements mean products that are concentrated sources of vitamins, minerals, or other substances with a nutritional or physiological effect (e.g., amino acids, essential fatty acids, probiotics, plants, and herbal extracts) intended to supplement the regular diet. Dietary supplements are produced in the form of capsules, tablets, pills, and other similar forms, designed to be taken in measured small unit quantities [1,2]. Dietary supplements, despite their route of administration and drug-like appearance, have been classified as foodstuffs and not medicines. Thus, in formal terms, supplement users are consumers rather than patients, but the question remains whether it is sick or healthy individuals who should be the primary users. The market for dietary supplements continues to expand at a rapid pace, and manufacturers develop products for health problems affecting almost all organs of the body, as well as for non-existing conditions, e.g., supplements for bladder elasticity. Additionally, a growing awareness among the public about the role of nutrition in the maintenance of health, together with widespread beliefs about today's food being poor in vitamins (e.g., due to impoverished soil), are among the reasons for dietary supplement use becoming common practice or even the norm.

Skyrocketing sales of supplements in times of the widespread accessibility and overconsumption of a wide range of foods may be described as the "supplement use phenomenon". In the US, over $50 \%$ of adults declare supplement use, and in some studies almost $40 \%$ had taken dietary supplements during the previous 30 days when they were questioned [3,4]. In Poland, supplement use has been reported by 30-78\% of adolescents and adults [5-7] and by approximately $40 \%$ of children [8]. Only one-quarter of supplement 
users take supplements recommended by their physician, meaning the overwhelming majority use dietary supplements of their own accord [9]. The primary reasons for supplement use in the United States are for overall health and wellness and to fill nutrient gaps in the diet [10], while in Poland, among the elderly it is a need to boost the immune system, and among younger people, use is related to improving the health and condition of skin and hair [7]. Moreover, more than $40 \%$ of Poles surveyed believe that taking vitamin and mineral supplements prevents diseases in healthy people, and almost $70 \%$ claim that the use of antioxidants prevents the development of cancers [11,12].

Due to the scale of supplement use, it is prudent to investigate whether and to what extent nutrient supplementation has beneficial effects and whether it lowers the risk of developing modern diseases. The aim of this scoping review is to present the state of knowledge about the effects of using selected dietary supplements in the context of the risk of developing non-communicable diseases typical of industrial societies, i.e., cardiovascular diseases, malignancies, and obesity, as well as supplements' possible treatment-supporting effects. Additionally, supplement safety, including their contamination with banned substances, is discussed.

\section{Materials and Methods}

In view of the vast quantities of supplements of different compositions and purposes, the author chose to review published scientific research on the most frequently taken dietary supplements, both in Poland and worldwide, which are primarily vitamins and minerals, followed by omega-3 fatty acids $[5,7,13,14]$. In the case of dietary supplements for weight loss, the most used ingredients were considered, i.e., chromium, chitosan, green tea extract, bitter orange, and Garcinia cambogia $[15,16]$.

Articles written in English were searched in PubMed and Medline using keywords (such as "dietary supplement", "food supplement", "vitamin-mineral preparations", "vitamins", "minerals", "omega-3 fatty acids", "weight loss supplements", "chromium", "chitosan", "green tea extract", "bitter orange" (Citrus aurantium), and "Garcinia cambogia" accompanied by the names of specific diseases (cardiovascular diseases, cancers, obesity) or the terms "safety" or "adulteration". This article mainly covers publications from the last decade, including randomized placebo-controlled trials, meta-analyses of such trials, and other original studies, as well as position statements by scientific societies. Due to the breadth of the issue, the literature review was limited to those studies involving adults, excluding studies on pregnant women.

\section{Results}

\subsection{Dietary Supplements and Cardiovascular Diseases}

Fatty saltwater fish, fruit, and vegetables are the most common dietary components contributing to cardiovascular disease prevention. The literature offers conclusive evidence that a high intake of omega-3 fatty acids from fish and seafood lowers the risk of cardiovascular disease incidence and mortality $[17,18]$ and that disease incidence is inversely correlated with fruit and vegetable consumption $[19,20]$.

\subsubsection{Polyunsaturated Omega-3 Fatty Acids}

The beneficial effect of omega-3 fatty acids, especially eicosapentaenoic acid (EPA), and docosahexaenoic acid (DHA), consists in their ability to reduce triglyceride concentration and to lower arterial pressure, as well as to inhibit inflammatory process and blood cell aggregation $[17,21]$. The well-documented importance of fish in the prevention of cardiovascular diseases resulted in a speedy market reaction and release of fish oil nutraceuticals. The question remains whether taking marine omega-3 fatty acid preparations is as beneficial as consuming marine omega- 3 fatty acid foods and whether they may become an alternative product for people who do not consume fish.

Regarding the primary prevention of cardiovascular disease, the results of two large, randomized trials from recent years should be cited first. One of them is the British 
ASCEND study that was conducted with a cohort of 15,480 patients (age $\geq 40$ years) with diabetes showing no evidence of atherosclerotic cardiovascular disease, who were administered either $840 \mathrm{mg}$ of marine omega-3 fatty acids or a placebo for an average of 7.4 years. This study showed no significant difference in the primary endpoints (i.e., nonfatal myocardial infarction, stroke, transient ischemic attack, or vascular death) or the secondary endpoints (first serious vascular event or any arterial revascularization) between the study and control groups. The authors concluded that the results of their study did not show that omega-3 fatty acids supplementation prevents vascular events [22]. In an American trial, the VITAL study, conducted with a group of 25,871 healthy individuals aged $\geq 50$ years, results revealed that consumption of $1 \mathrm{~g}$ of fish oil/day $(840 \mathrm{mg}$ EPA and DHA) for a median of 5.3 years did not lower the risk of myocardial infarction, stroke, or overall cardiovascular mortality in the study group compared with the placebo group [23].

Studies have also assessed omega-3 fatty acid supplementation in relation to secondary prevention. The REDUCE-IT Clinical Trial showed that administration of highly purified EPA ethyl ester (icosapent ethyl) at $4 \mathrm{~g}(2 \mathrm{~g}$, twice daily) for a median of 4.9 years to patients with atherosclerotic cardiovascular disease or diabetes, who have elevated triglycerides and are treated with statins, reduced the risk of cardiovascular death, nonfatal myocardial infarction, non-fatal stroke, coronary revascularization, or unstable angina by $25 \%$, compared with placebo, and reduced the risk of the secondary endpoint (cardiovascular death, non-fatal myocardial infarction, or non-fatal stroke) by $26 \%$. The authors emphasized that the benefits demonstrated in their study should not be transferred to all omega-3 preparations, especially dietary supplements, due to the differences between the composition of supplements compared with the preparation used in their study [24]. The literature also shows that $4 \mathrm{~g}$ of icosapent ethyl improves the lipid profile in patients with statin intolerance [25]. Many other experts also emphasize that omega-3 fatty acids (of proven quality) may be particularly beneficial for statin-intolerant patients with obesity, diabetes, or metabolic syndrome in whom elevated LDL cholesterol is accompanied by high levels of triglycerides [26].

However, the STRENGTH randomized clinical trial of 2020 did not provide optimistic results. In that study, administration of $4 \mathrm{~g}$ of an omega- 3 preparation with increased bioavailability (carboxylic acid formulation of EPA and DHA) to high cardiovascular risk patients treated with statins for more than 3 years proved of no benefit in terms of major cardiovascular events, and this finding resulted in early termination of the study [27]. As experts point out, such divergent results of single studies may result from different proportions of individual fatty acids in the preparations, the doses of the preparations, the length of the study, or the varying initial concentrations of omega-3 in the blood of the patients [28].

To obtain clearer data in such situations, conclusions from meta-analyses of randomized controlled trials are typically used, and though these have been quite numerous in the past 10 years, their results do not provide sufficient evidence to form an unambiguous conclusion. The findings of three 2012 meta-analyses showed that omega-3 fatty acid supplementation did not lower the risk of myocardial infarction, stroke, cerebrovascular events, cardiovascular mortality [29,30], or cardiovascular incidents in patients with existing cardiovascular diseases [31]. A meta-analysis published one year later revealed that supplementation with omega- 3 fatty acids reduced the risk of myocardial infarction by $25 \%$ and the risk of cardiac death by $32 \%$ in patients with cardiovascular diseases [32], while a meta-analysis published in 2014 reported a 12\% reduction in death from cardiac causes in patients with coronary heart disease who took omega-3 fatty acids [33]. In turn, a 2018 meta-analysis of randomized studies of omega-3 fatty acids taken, showed no effects on non-fatal myocardial infarction, coronary heart disease events, or major vascular events [34], a finding that is consistent with another 2018 meta-analysis that also showed no relationship between omega- 3 fatty acids consumption and lowered risk of cardiovascular disorders [35]. In contrast, the results of one of two 2019 meta-analyses of randomized clinical trials showed that taking omega- 3 fatty acids reduced the risk of major 
vascular events by $5 \%$, non-fatal myocardial infarction by $11 \%$, and death by coronary heart disease by $9 \%$ [36]. The second 2019 meta-analysis of the studies, from which the REDUCE-IT study was excluded because of the comparatively high level of its omega-3 dose, showed that omega-3 supplementation was associated with lower risk of myocardial infarction by $8 \%$, total coronary heart disease by $5 \%$, coronary heart disease death by $8 \%$, and cardiovascular death by $7 \%$ [37]. Further evidence of the beneficial effect of omega-3 fatty acids in reducing cardiovascular risk is also found in the results of two meta-analyses from 2020 [38,39], although there was also an associated higher risk of bleeding events and atrial fibrillation events in some instances [39].

Against the background of the current state of scientific knowledge, what are the positions of the scientific societies responsible for recommendations to the medical community?

The International Lipid Expert Panel (ILEP) stated in 2017 that omega-3 fatty acids are proven to lower triglycerides (scientific evidence: class I, level A) [40,41] and added to this view in 2020 by indicating the need for EPA and DHA supplementation in heart failure, especially in patients after myocardial infarction [42]. According to the ILEP, omega-3 fatty acids in doses of 1-4 g daily reduce triglyceride levels by 18-25\% [40]. The European Society of Cardiology (ESC) and the European Atherosclerosis Society (EAS) both state that doses of 2-3 g reduce triglyceride levels by about 30\% [43]. The European Society of Cardiology and other societies on cardiovascular disease prevention in clinical practice, as of 2019, did not recommend omega-3 fatty acid supplementation for cardiovascular diseases prevention due to the lack of reliable proof of its beneficial effects [20]. Meanwhile, the 2019 American College of Cardiology/American Heart Association guideline on the primary prevention of cardiovascular disease makes no mention of omega-3 fatty acids [44], which should be understood as a lack of support for their use. The American Heart Association stated in 2017 that supplementation of omega-3 fatty acids would be beneficial in patients with coronary heart disease (CHD), including those after heart attack, as it may lower the risk of CHD-related mortality by $10 \%$ [45].

In conclusion, research findings on the impact of omega-3 fatty acid supplementation on the risks or benefits in relation to the treatment of cardiovascular diseases vary significantly. However, there are many indications that taking omega-3 fatty acid preparations by healthy people do not have such beneficial effects as eating the same fats in fish. Therefore, consumption of omega-3 capsules does not offer an easy way to improve nutrition and, apparently, cannot serve as a substitute for fish and seafoods in the diet. Importantly, recent years have brought a growing number of reports about low-quality fish oil supplements [46], which according to various authors are nowhere near as good as preparations registered as medicines [47]. In New Zealand, as many as $83 \%$ of supplements containing fish oils were shown to exceed permissible levels of peroxides, which are an indicator of fat deterioration [48]; similarly, in the US, oxidized fatty acids, cholesterol, and toxins were found in many omega-3 supplements [49]. In Poland, there is a wide range of supplement products on the market containing omega-3 fatty acids and, as is the case throughout the European Union, there is no legal requirement for standardization of such preparations regarding individual fatty acids content [21]. Currently, however, there are no data on the contamination of such preparations in Poland.

\subsubsection{Vitamins and Minerals}

Vitamins and minerals are essential substances that our bodies need for optimal functioning. As there is a considerable selection of vitamin and mineral supplements, it seems prudent to consider whether they bring any benefits in terms of cardiovascular disease prevention. As far as arterial hypertension is concerned, a prospective study by Rautiainen et al. [50] found no relationship between vitamin supplementation and the risk of developing hypertension in healthy women. Wang et al. [51], who investigated obese women with increased cardiovascular disease risk in a randomized study, reported that a 26-week supplementation with a vitamin-mineral preparation significantly lowered blood pressure compared with the placebo given to the control group. 
The authors of the 2018 meta-analysis of randomized studies concluded that vitaminmineral supplementation does not lower the risk of developing hypertension but, at the same time, suggested that such preparations may have a beneficial effect in subjects with hypertension [52]. The benefits of potassium supplementation have been extensively documented. Experts believe that potassium supplementation in patients with hypertension supports treatment and may be recommended [53,54].

As for other endpoints of studies on vitamins and minerals intake and cardiovascular diseases, Park et al. [55] conducted a study in over 180,000 people in the US and found that multivitamin preparations do not inversely correlate with cardiovascular mortality. Additionally, a randomized study in the US with more than 14,000 physicians reported no positive effects of supplementation, either with single-preparation vitamin $C, E$, and beta-carotene or multivitamin preparation, with regard to cardiovascular incidents in either healthy subjects or individuals with cardiovascular disease [56]. Randomized trials also do not reveal the benefits of B vitamins (folic acid, vitamins B6, and B12) supplementation in patients with pre-existing cardiovascular disease. Equally, in the study by Albert et al. and Galan et al., no significant effect on the risk of major cardiovascular events was found $[57,58]$. However, it should be mentioned that optimistic results were obtained in a Chinese study of taking enalapril (a drug for treating high blood pressure) in combination with folic acid. In this large randomized study, conducted among adults with hypertension without a history of stroke or myocardial infarction, the combined use of enalapril and folic acid ( $0.8 \mathrm{mg} /$ day), compared with enalapril alone, reduced the risk of the first stroke by $21 \%$ and the risk of composite cardiovascular events by $20 \%$ [59].

A meta-analysis of clinical trials and prospective cohort studies reported no relationship between vitamin-mineral supplementation and the incidence of stroke and the risk of cardiovascular mortality in the general population [60]. An umbrella review of 2019 [61] also found no effect of vitamin preparations on the development of cardiovascular diseases and cardiovascular mortality. For years, the US Preventive Services Task Force panel of experts has not been recommending vitamin-mineral supplementation for cardiovascular disease prevention in people without confirmed insufficiency $[62,63]$.

\subsubsection{Antioxidants}

Although no universal definition of antioxidants exists in the literature, it is believed that they are compounds that donate one of their electrons or hydrogen to free radicals, stopping their chain reaction [64]. Some vitamins and minerals (vitamins A, C, E, betacarotene, selenium, and zinc) are classified as antioxidants and are a subcategory of dietary supplements [65]. Antioxidants prevent the negative effects of free radicals, inhibit the oxidative process, and reduce inflammation in the body. The deficiency of these nutrients in the body may increase the risk of developing a variety of conditions, including cardiovascular diseases $[52,66]$. Antioxidant supplementation has been extensively researched, but the findings remain inconclusive, especially in the case of vitamin $E[13,67,68]$.

In a study by Lee et al. [69], daily supplementation with 600 IU of vitamin E by healthy women for 10 years did not alter the incidence of myocardial infarction and stroke as compared with the study's control group taking placebos, but it did lower the risk of cardiovascular mortality by $24 \%$. Lonn et al., [70] not only found that vitamin E supplementation (400 IU/day for a median of 7 years) failed to reduce the risk of cardiovascular incidence in affected individuals but also found that it increased the risk of heart failure by $13 \%$. The results of a recently published Mendelian randomization study indicated that genetically conditioned higher blood concentrations of vitamin E elevated the concentrations of LDL cholesterol and triglycerides, decreased HDL concentration, and increased the risk of coronary artery disease [71].

The results of several meta-analyses of randomized studies published over the years also remain inconclusive. In a 2003 meta-analysis of multiple studies, vitamin E (50-800 IU) administered for 1.4-12 years was shown to have no beneficial effect on cardiovascular mortality rates, and its routine use was not recommended [72]. A meta-analysis published 
in 2015 concluded that vitamin E supplementation reduces the risk of cardiac infarction, but the effect is negated when it is administered together with other antioxidants [73]. Yet another meta-analysis from 2017 reported beneficial effects of single-preparation vitamin E-namely, a $12 \%$ reduction of the risk of cardiovascular mortality. However, the authors found no justification for administration of other antioxidants, i.e., vitamin C, selenium, and zinc [13]. The International Lipid Expert Panel believes that current research results do not show any benefits of vitamin E supplementation in the prevention or treatment of heart failure, and they draw a similar conclusion for vitamin C [40].

Findings regarding beta-carotene are less optimistic. According to a meta-analysis of randomized studies, beta-carotene at a dose of $15-50 \mathrm{mg}$ for 1.4-12 years has led to a slight but statistically significant increase in cardiovascular mortality [72]. The US Preventive Services Task Force panel of experts also opposes the use of both beta-carotene and vitamin $\mathrm{E}$ in cardiovascular disease prevention [74]. The most radical position on antioxidant supplementation has been taken by the authors of the "Enough is enough: Stop wasting money on vitamin and mineral supplements", who claim that a sufficient number of studies have demonstrated the lack of benefits of vitamin-mineral supplementation to warrant ceasing any further research on their effectiveness [75].

In summary, based on the available literature, it seems safe to conclude that supplementation with vitamin-mineral preparations whose intake exceeds the needs of the body is not a recommended method of cardiovascular disease prevention. Table 1 summarizes the studies included in this paper, showing relationships between dietary supplement use and cardiovascular health.

Table 1. Characteristic of studies evaluating the effect of selected dietary supplements on cardiovascular diseases.

\begin{tabular}{|c|c|c|c|c|c|}
\hline Authors & Study Design & Participants & $\begin{array}{l}\text { Type of Dietary } \\
\text { Supplements }\end{array}$ & $\begin{array}{l}\text { Duration of the } \\
\text { Study }\end{array}$ & Results \\
\hline $\begin{array}{c}\text { The ASCEND Study } \\
\text { Collaborative Group } \\
2018 \text { [22] }\end{array}$ & $\mathrm{RCT}$ & $\begin{array}{l}15,480 \text { patients with } \\
\text { diabetes aged } \\
\geq 40 \text { years }\end{array}$ & $\begin{array}{l}\text { Omega-3 fatty } \\
\text { acids }\end{array}$ & Mean: 7.4 years & $\begin{array}{l}\text { No effect on serious } \\
\text { vascular events }\end{array}$ \\
\hline Manson et al., 2019 [23] & $\mathrm{RCT}$ & $\begin{array}{l}25,871 \text { patients aged } \\
\geq 50 \text { years }\end{array}$ & $\begin{array}{l}\text { Omega-3 fatty } \\
\text { acids }\end{array}$ & Median: 5.3 years & $\begin{array}{c}\text { No effect on } \\
\text { cardiovascular events }\end{array}$ \\
\hline Bhatt et al., 2019 [24] & $\mathrm{RCT}$ & $\begin{array}{l}8179 \text { patients with } \\
\text { cardiovascular } \\
\text { diseases or diabetes, } \\
\text { median age: } 64 \text { years }\end{array}$ & $\begin{array}{c}\text { Purified EPA ethyl } \\
\text { ester (icosapent } \\
\text { ethyl) }\end{array}$ & Median: 4.9 years & $\begin{array}{l}\text { 25\% reduction in primary } \\
\text { endpoints: cardiovascular } \\
\text { death, non-fatal MI, } \\
\text { non-fatal stroke, coronary } \\
\text { revascularization, } \\
\text { unstable angina; } \\
26 \% \text { reduction in } \\
\text { secondary endpoints: } \\
\text { cardiovascular death, } \\
\text { non-fatal MI, } \\
\text { non-fatal stroke }\end{array}$ \\
\hline Nicholls et al., 2020 [27] & $\mathrm{RCT}$ & $\begin{array}{l}13,078 \text { patients with } \\
\text { high cardiovascular } \\
\text { risk, mean age: } \\
62.5 \text { years }\end{array}$ & $\begin{array}{l}\text { Omega-3 fatty } \\
\text { acids }\end{array}$ & Over 3 years & $\begin{array}{l}\text { No effect on major } \\
\text { cardiovascular events }\end{array}$ \\
\hline Rizos et al., 2012 [29] & $\begin{array}{l}\text { Systematic review } \\
\text { and meta-analysis, } \\
20 \text { RCTs }\end{array}$ & $\begin{array}{c}68,680 \text { patients aged } \\
49-70 \text { years }\end{array}$ & $\begin{array}{l}\text { Omega-3 fatty } \\
\text { acids }\end{array}$ & Median: 2.0 years & $\begin{array}{l}\text { No effect on cardiac } \\
\text { death, MI, and stroke }\end{array}$ \\
\hline Kotwal et al., 2012 [30] & $\begin{array}{l}\text { Meta-analysis, } \\
20 \text { RCTs }\end{array}$ & $\begin{array}{l}\text { 62,851 patients in } \\
\text { primary and } \\
\text { secondary prevention } \\
\text { settings }\end{array}$ & $\begin{array}{l}\text { Omega-3 fatty } \\
\text { acids }\end{array}$ & 6 months -6 years & $\begin{array}{c}\text { 14\% reduction in vascular } \\
\text { death; } \\
\text { no effect on } \\
\text { cardiovascular events, } \\
\text { coronary events, } \\
\text { cerebrovascular } \\
\text { events, arrhythmia }\end{array}$ \\
\hline
\end{tabular}


Table 1. Cont.

\begin{tabular}{|c|c|c|c|c|c|}
\hline Authors & Study Design & Participants & $\begin{array}{l}\text { Type of Dietary } \\
\text { Supplements }\end{array}$ & $\begin{array}{l}\text { Duration of the } \\
\text { Study }\end{array}$ & Results \\
\hline Kwak et al., 2012 [31] & $\begin{array}{l}\text { Meta-analysis, } \\
14 \text { RCTs }\end{array}$ & $\begin{array}{l}\text { 20,485 patients with } \\
\text { cardiovascular } \\
\text { diseases aged } \\
40-80 \text { years }\end{array}$ & $\begin{array}{l}\text { Omega-3 fatty } \\
\text { acids }\end{array}$ & $1.0-4.7$ years & $\begin{array}{l}\text { No effect on } \\
\text { cardiovascular events, } \\
\text { MI, congestive heart } \\
\text { failure, and stroke }\end{array}$ \\
\hline Casula et al., 2013 [32] & $\begin{array}{l}\text { Meta-analysis, } \\
11 \text { RCTs }\end{array}$ & $\begin{array}{l}\text { 15,348 patients with } \\
\text { cardiovascular } \\
\text { diseases }\end{array}$ & $\begin{array}{l}\text { Omega-3 fatty } \\
\text { acids }\end{array}$ & $1.0-3.5$ years & $\begin{array}{c}32 \% \text { reduction in cardiac } \\
\text { death, } \\
25 \% \text { reduction in } \mathrm{MI} ; \\
\text { no effect on stroke }\end{array}$ \\
\hline Wen et al., 2014 [33] & $\begin{array}{l}\text { Meta-analysis, } \\
14 \text { RCTs }\end{array}$ & $\begin{array}{l}\text { 32,656 patients with } \\
\text { CHD }\end{array}$ & $\begin{array}{l}\text { Omega-3 fatty } \\
\text { acids }\end{array}$ & $\begin{array}{c}<3 \\
\text { months }-4.6 \text { years }\end{array}$ & $\begin{array}{l}12 \% \text { reduction in death } \\
\text { from cardiac causes, } 14 \% \\
\text { reduction in sudden } \\
\text { cardiac death }\end{array}$ \\
\hline $\begin{array}{c}\text { Abdelhamid et al., } \\
2018 \text { [35] }\end{array}$ & $\begin{array}{l}\text { Meta-analysis, } \\
79 \text { RCTs }\end{array}$ & $\begin{array}{c}112,059 \text { adults in } \\
\text { primary and } \\
\text { secondary prevention } \\
\text { settings }\end{array}$ & $\begin{array}{l}\text { Omega-3 fatty } \\
\text { acids }\end{array}$ & $12-72$ months & $\begin{array}{l}\text { Little or no effect on } \\
\text { cardiovascular mortality, } \\
\text { CHD mortality, } \\
\text { cardiovascular events, } \\
\text { stroke, arrhythmia }\end{array}$ \\
\hline Aung et al., 2018 [34] & $\begin{array}{l}\text { Meta-analysis, } \\
10 \text { RCTs }\end{array}$ & $\begin{array}{l}\text { 77,917 high-risk } \\
\text { patients }\end{array}$ & $\begin{array}{l}\text { Omega- } 3 \text { fatty } \\
\text { acids }\end{array}$ & $1.0-6.2$ years & $\begin{array}{l}\text { No effect on CHD } \\
\text { mortality, non-fatal MI, } \\
\text { CHD events, major } \\
\text { vascular events }\end{array}$ \\
\hline Mazidi et al., 2019 [36] & $\begin{array}{l}\text { Meta-analysis, } \\
13 \text { RCTs }\end{array}$ & 127,447 patients & $\begin{array}{l}\text { Omega-3 fatty } \\
\text { acids }\end{array}$ & No data & $\begin{array}{l}9 \% \text { reduction in CHD } \\
\text { death, } 5 \% \text { reduction in } \\
\text { major vascular event, } 11 \% \\
\text { reduction in non-fatal MI, } \\
5 \% \text { reduction in all-cause } \\
\text { mortality }\end{array}$ \\
\hline Hu et al., 2019 [37] & $\begin{array}{l}\text { Meta-analysis, } \\
13 \text { RCTs }\end{array}$ & $\begin{array}{l}127,447 \text { patients, } \\
\text { mean age: } 64.3 \text { years }\end{array}$ & $\begin{array}{l}\text { Omega-3 fatty } \\
\text { acids }\end{array}$ & 5 years & $\begin{array}{l}8 \% \text { reduction in MI, } 8 \% \\
\text { reduction in CHD death, } \\
5 \% \text { reduction in total } \\
\text { CHD, } 7 \% \text { reduction in } \\
\text { CVD death, } 3 \% \text { reduction } \\
\text { in total CVD }\end{array}$ \\
\hline Casula et al., 2020 [38] & $\begin{array}{l}\text { Meta-analysis, } \\
16 \text { RCTs }\end{array}$ & 81,073 participants & $\begin{array}{l}\text { Omega- } 3 \text { fatty } \\
\text { acids }\end{array}$ & $\geq 1$ year & $\begin{array}{l}9 \% \text { reduction in cardiac } \\
\text { mortality, } 10 \% \text { reduction } \\
\text { in major adverse } \\
\text { cardiovascular events, } \\
17 \% \text { reduction in MI; } \\
\text { more benefits were seen } \\
\text { in secondary prevention }\end{array}$ \\
\hline $\begin{array}{l}\text { Lombardi et al., } \\
2020 \text { [39] }\end{array}$ & $\begin{array}{l}\text { Meta-analysis, } 14 \\
\text { studies }\end{array}$ & 125,763 patients & $\begin{array}{l}\text { Omega- } 3 \text { fatty } \\
\text { acids }\end{array}$ & Median: 4.6 years & $\begin{array}{l}21 \% \text { reduction in cardiac } \\
\text { death, } 29 \% \text { reduction in } \\
\text { MI, } 26 \% \text { reduction in } \\
\text { coronary } \\
\text { revascularization, } 27 \% \\
\text { reduction in unstable } \\
\text { angina, and } 22 \% \\
\text { reduction in major } \\
\text { vascular events-for } \\
\text { high-dose omega-3 fatty } \\
\text { acids (> } 1 \text { g per day); } \\
49 \% \text { increase in bleeding } \\
\text { events and } 35 \% \text { increase } \\
\text { in atrial fibrillation } \\
\text { events-for high-dose } \\
\text { omega-3 fatty acids }(>1 \mathrm{~g} \\
\text { per day) }\end{array}$ \\
\hline
\end{tabular}


Table 1. Cont.

\begin{tabular}{|c|c|c|c|c|c|}
\hline Authors & Study Design & Participants & $\begin{array}{l}\text { Type of Dietary } \\
\text { Supplements }\end{array}$ & $\begin{array}{l}\text { Duration of the } \\
\text { Study }\end{array}$ & Results \\
\hline Wang et al., 2009 [51] & $\mathrm{RCT}$ & $\begin{array}{c}128 \text { obese women } \\
\text { aged } 18-50 \text { years } \\
\text { with hypertension } \\
\text { or/and } \\
\text { hyperglycemia, } \\
\text { and/or hyperlipemia }\end{array}$ & $\begin{array}{l}\text { Multivitamins and } \\
\text { minerals }\end{array}$ & 26 weeks & $\begin{array}{l}\text { Significant reduction of } \\
\text { systolic and diastolic BP }\end{array}$ \\
\hline Park et al., 2011 [55] & Cohort study & $\begin{array}{c}182,099 \text { patients aged } \\
45-75 \text { years }\end{array}$ & Multivitamins & Mean: 11 years & $\begin{array}{c}\text { No effect on mortality } \\
\text { from cardiovascular } \\
\text { diseases }\end{array}$ \\
\hline Sesso et al., 2012 [56] & $\mathrm{RCT}$ & $\begin{array}{l}\text { 14,641 males aged } \\
\quad \geq 50 \text { years }\end{array}$ & Multivitamins & $10.7-13.3$ years & $\begin{array}{l}\text { No effect on } \\
\text { cardiovascular events, } \\
\text { MI, stroke, cardiovascular } \\
\text { disease mortality }\end{array}$ \\
\hline $\begin{array}{l}\text { Rautiainen et al., } \\
\quad 2016 \text { [50] }\end{array}$ & $\begin{array}{l}\text { Prospective cohort } \\
\text { study }\end{array}$ & $\begin{array}{c}28,157 \text { women aged } \\
\geq 45 \text { years free of } \\
\text { hypertension at } \\
\text { baseline }\end{array}$ & Multivitamins & Mean: 11.5 years & $\begin{array}{l}\text { No association with the } \\
\text { risk of hypertension }\end{array}$ \\
\hline Albert et al., 2008 [57] & $\mathrm{RCT}$ & $\begin{array}{l}5442 \text { women with a } \\
\text { history of } \\
\text { cardiovascular } \\
\text { diseases or three or } \\
\text { more coronary risk } \\
\text { factors aged } \\
\geq 40 \text { years }\end{array}$ & $\begin{array}{l}\text { Folic acid, vitamin } \\
\text { B6, vitamin B12 }\end{array}$ & 7.3 years & $\begin{array}{l}\text { No significant effect on } \\
\text { risk of major } \\
\text { cardiovascular events }\end{array}$ \\
\hline Galan et al., 2010 [58] & $\mathrm{RCT}$ & $\begin{array}{l}2501 \text { patients with a } \\
\text { history of ischemic } \\
\text { heart disease or } \\
\text { stroke, mean age: } \\
60.9 \text { years }\end{array}$ & $\begin{array}{l}\text { Folic acid, vitamin } \\
\text { B6, vitamin B12 }\end{array}$ & Median: 4.7 years & $\begin{array}{l}\text { No significant effect on } \\
\text { risk of major } \\
\text { cardiovascular events }\end{array}$ \\
\hline Huo et al., 2015 [59] & RCT & $\begin{array}{l}20,702 \text { patients with } \\
\text { hypertension, } \\
\text { without a history of } \\
\text { stroke or myocardial } \\
\text { infarction aged } \\
45-75 \text { years }\end{array}$ & Enalapril, folic acid & Median: 4.5 years & $\begin{array}{l}21 \% \text { reduction in first } \\
\text { stroke and } 20 \% \text { reduction } \\
\text { in composite } \\
\text { cardiovascular events }\end{array}$ \\
\hline Lee et al., 2005 [69] & $\mathrm{RCT}$ & $\begin{array}{l}39,876 \text { healthy } \\
\text { women aged } \\
\geq 45 \text { years }\end{array}$ & Vitamin E & Mean: 10.1 years & $\begin{array}{l}\text { No effect on MI, stroke; } \\
24 \% \text { reduction in } \\
\text { cardiovascular death }\end{array}$ \\
\hline Lonn et al., 2005 [70] & RCT & $\begin{array}{c}9541 \text { patients with } \\
\text { vascular disease or } \\
\text { diabetes }\end{array}$ & Vitamin E & Median: 7.0 years & $\begin{array}{l}13 \% \text { increase in heart } \\
\text { failure }\end{array}$ \\
\hline Wang et al., 2019 [71] & $\begin{array}{l}\text { Mendelian } \\
\text { randomization } \\
\text { study }\end{array}$ & 7781 participants & Vitamin E & No data & $\begin{array}{l}\text { Genetically determined } \\
\text { higher blood levels of } \\
\text { vitamin E increases the } \\
\text { risk of CAD and MI, } \\
\text { increases the } \\
\text { concentration of LDL } \\
\text { cholesterol and } \\
\text { triglycerides, decreases } \\
\text { HDL cholesterol } \\
\text { concentration }\end{array}$ \\
\hline $\begin{array}{c}\text { Schwingshackl et al., } \\
2017 \text { [13] }\end{array}$ & $\begin{array}{l}\text { Meta-analysis, } \\
49 \text { RCTs }\end{array}$ & 287,304 participants & $\begin{array}{l}\text { Vitamins and } \\
\text { minerals }\end{array}$ & $1.0-11.2$ years & $\begin{array}{l}12 \% \text { reduction in } \\
\text { cardiovascular mortality } \\
\text { with vitamin E } \\
\text { supplementation; } \\
\text { no beneficial effect from } \\
\text { other vitamin/mineral } \\
\text { supplementation }\end{array}$ \\
\hline Kim et al., 2018 [60] & $\begin{array}{l}\text { Meta-analysis, } 18 \\
\text { clinical trials and } \\
\text { prospective cohort } \\
\text { studies }\end{array}$ & $2,019,862$ participants & $\begin{array}{l}\text { Multivitamins and } \\
\text { minerals }\end{array}$ & 5.0-19.1 years & $\begin{array}{c}\text { No effect on } \\
\text { cardiovascular mortality, } \\
\text { CHD mortality, stroke } \\
\text { mortality, stroke } \\
\text { incidence }\end{array}$ \\
\hline
\end{tabular}


Table 1. Cont.

\begin{tabular}{|c|c|c|c|c|c|}
\hline Authors & Study Design & Participants & $\begin{array}{l}\text { Type of Dietary } \\
\text { Supplements }\end{array}$ & $\begin{array}{l}\text { Duration of the } \\
\text { Study }\end{array}$ & Results \\
\hline Li et al., 2018 [52] & $\begin{array}{l}\text { Meta-analysis, } \\
12 \text { RCTs }\end{array}$ & $\begin{array}{l}23,207 \text { patients aged } \\
21.9-64.7 \text { years }\end{array}$ & $\begin{array}{l}\text { Multivitamins and } \\
\text { minerals }\end{array}$ & 1.0-86.4 months & $\begin{array}{l}\text { No effect on risk of } \\
\text { hypertension; significant } \\
\text { reduction of systolic BP } \\
\text { in subjects with } \\
\text { hypertension }\end{array}$ \\
\hline Khan et al., 2019 [61] & $\begin{array}{c}\text { An umbrella } \\
\text { review: } 9 \\
\text { systematic review, } \\
4 \text { RCTs, } 105 \\
\text { meta-analyses }\end{array}$ & 992,129 participants & $\begin{array}{l}\text { Multivitamins and } \\
\text { antioxidants }\end{array}$ & No data & $\begin{array}{c}\text { No effect on } \\
\text { cardiovascular diseases } \\
\text { outcomes }\end{array}$ \\
\hline Loffredo et al., 2015 [73] & $\begin{array}{l}\text { Meta-analysis, } \\
16 \text { RCTs }\end{array}$ & $\begin{array}{l}\text { Up to } 39,876 \text { patients } \\
\text { aged }>50 \text { years }\end{array}$ & Antioxidants & $0.5-9.4$ years & $\begin{array}{l}18 \% \text { reduction in MI with } \\
\text { vitamin } \mathrm{E} \\
\text { supplementation }\end{array}$ \\
\hline $\begin{array}{l}\text { Vivekananthan et al., } \\
2003 \text { [72] }\end{array}$ & $\begin{array}{l}\text { Meta-analysis, } \\
32 \text { RCTs }\end{array}$ & 81,788 patients & $\begin{array}{l}\text { Vitamin E, beta- } \\
\text { carotene }\end{array}$ & $1.4-12.0$ years & $\begin{array}{c}\text { No effect from } \\
\text { supplementation of } \\
\text { vitamin E on } \\
\text { cardiovascular mortality, } \\
\text { cerebrovascular events; } \\
\text { significant increase in } \\
\text { cardiovascular death } \\
\text { with beta-carotene } \\
\text { supplementation }\end{array}$ \\
\hline $\begin{array}{l}\text { Poorolajal et al., } \\
\quad 2017 \text { [53] }\end{array}$ & $\begin{array}{l}\text { Meta-analysis, } \\
23 \text { RCTs }\end{array}$ & $\begin{array}{l}1213 \text { patients with } \\
\text { hypertension, mean } \\
\text { age: } 19-75 \text { years }\end{array}$ & Potassium & 4-52 weeks & $\begin{array}{l}\text { Significant reduction of } \\
\text { systolic and diastolic BP }\end{array}$ \\
\hline Filippini et al., 2020 [54] & $\begin{array}{l}\text { Meta-analysis, } \\
32 \text { RCTs }\end{array}$ & $\begin{array}{c}1764 \text { patients mainly } \\
\text { with hypertension } \\
\text { aged } 18-79 \text { years }\end{array}$ & Potassium & 4-15 weeks & $\begin{array}{l}\text { Significant reduction of } \\
\text { systolic and diastolic BP }\end{array}$ \\
\hline
\end{tabular}

Abbreviations: RCT—randomized controlled trial; MI—myocardial infarction; CHD—coronary heart disease; CAD—coronary artery disease; $\mathrm{BP} —$ blood pressure.

\subsection{Dietary Supplements and Malignancy}

\subsubsection{Cancer Prevention}

According to the literature, the effects of vitamin and mineral consumption on the risk of developing cancer has a U-shaped distribution (the dose-response curve). Optimal intake of these components (the range that corresponds with the base of the curve) is associated with lower risk of the disease, whereas both insufficiency and excessive consumption may promote carcinogenesis $[9,76]$.

In light of the growing popularity of the so-called "Western diet", it seems prudent to ask whether vitamin and mineral supplementation may in fact reduce the development of cancer and whether it brings any additional benefits in people with healthy diets. A randomized study of vitamin C (500 mg/day) and E (400 IU every other day) supplementation and cancer incidence in men, by Gaziano et al., [77] found no differences between the study group and the placebo control group; similarly, Lee et al. [69] demonstrated no benefits of vitamin E supplementation (600 IU every other day) in women. The results of a multi-center Selenium and Vitamin E Cancer Prevention Trial are even less favorable, finding that vitamin E supplementation (400 IU/day) increased the risk of prostate cancer by $17 \%$ [78]. Additionally, in a long-term prospective study by Park et al., no relationship was found between multivitamin supplementation and cancer development [55].

All hope that health improvements derive from vitamin supplementation was abandoned after the results of studies on beta-carotene were published. In fact, those studies may even be considered as an argument against supplementation. There is an accumulating body of evidence that suggests that beta-carotene, a typical antioxidant, may in fact exert a pro-oxidative effect in smokers [79]. CARET, one of the first randomized trials conducted in the 1980s, demonstrated that administration of $30 \mathrm{mg}$ of beta-carotene and $25,000 \mathrm{UI}$ of retinol per day for an average of 4 years resulted in a $28 \%$ increased risk of lung 
cancer and a $17 \%$ higher risk of mortality [80]. These unexpected results led to the study being prematurely terminated. Another randomized study, conducted with male smokers from Finland between 1985 and 1993, included a similar conclusion. Supplementation with beta-carotene at a dose of $20 \mathrm{mg}$ /day for an average of 6 years increased the risk of lung cancer by $16 \%$ [81], and further analysis showed that the increased risk did not correlate with nicotine and tar contents in the cigarettes [82]. A Japanese study on vitamin A intake in the diet also generated unfavorable results. Higher consumption of vitamin A was associated with a $26 \%$ greater risk of lung cancer [83]. Based on the meta-analyses of high-quality randomized trials, it seems that antioxidant administration (vitamin A, C, E, selenium, and zinc combined) in healthy individuals does not lower the risk of developing lung cancer. Vitamin C supplementation increased the risk of malignancy in women by $84 \%$, and similarly, vitamin A increased the risk in smokers and people with history of asbestos exposure by $10 \%$ [84]. Studies have also shown that antioxidant supplementation produces no benefits in the prevention of bladder [79] or colorectal cancers [85].

According to some experts, antioxidant supplementation in cancer prevention may only be beneficial in healthy people with vitamin insufficiency. High doses of antioxidants may even be harmful to people in the subclinical phases of the disease $[76,86]$. Selenium is a good example of the thin line between beneficial and detrimental doses when the relationship between antioxidant consumption and the risks of developing cancer are concerned. In people with low blood concentrations of selenium, its supplementation lowers cancer risk, but in individuals with high blood concentrations of selenium, supplementation increases the risk of developing lung cancer $[87,88]$.

Vitamin D supplementation has also caused a lot of interest in recent years in relation to cancer prevention because of the vitamin's anti-inflammatory and immunomodulatory properties and the presence of Vitamin D Receptor (VDR) in most human organs. However, meta-analysis of randomized controlled trials has not confirmed that vitamin D intake reduces the incidence of cancer [89-91].

Summarizing the current state of knowledge about vitamin and mineral supplementation in cancer prevention, it is important to emphasize that the expert panel of the World Cancer Research Fund opposes the use of such preparations [92], as does the American Cancer Society, which, in addition, has concluded that if, despite the absence of benefits, one chooses to take vitamin-mineral supplements, doses exceeding $100 \%$ of the daily demand should not be used [76]. According to the U.S. Preventive Services Task Force panel of experts, we lack sufficient data to determine the role of vitamin preparations in cancer prevention, except for beta-carotene and vitamin E, whose supplementation is universally discouraged [74].

\subsubsection{Cancer Therapy}

Supplement use among cancer patients is common and typically unsupervised by a physician. Alternative medicine therapies, including "word-of-mouth" dietary supplement recommendations, are believed to be safe and complementary to the therapeutic process $[74,88]$. A study by Mandecka et al. [66] demonstrated that over $46 \%$ of cancer patients used dietary supplements, mostly antioxidants, although the patients' mean intake of vitamin A, C, and $\mathrm{E}$ from food ranged between $200 \%$ and $300 \%$ of the daily requirements. According to the literature, $64-81 \%$ of cancer patients take vitamins or minerals, and $26-77 \%$ use multivitamin preparations $[93,94]$. Presumably, three-quarters of the physicians are not aware of what the patients take of their own accord, following the rule "patient keeps quiet, doctor asks no questions". The case of shark cartilage is an interesting example of the difference between popular perception and proven efficacy, as it was extremely popular in the 1990s, although it was utterly ineffective as a dietary supplement allegedly helpful in fighting cancer [95].

Vitamin C, due to its antioxidative action and positive effect on the immune system, has been immensely popular among cancer patients. However, randomized studies showed no indication that supplementation may provide favorable results [96]. In the case of the 
impact of vitamin D supplementation, some meta-analyses of randomized controlled trials indicate that vitamin $\mathrm{D}$ intake reduces the risk of cancer mortality by $12-13 \%$ [90,91]. However, some authors note that due to the low quality of the research, this finding should be approached with caution [91] and yet others do not confirm any relationship [89]. Decisions about possible vitamin D supplementation in cancer patients should consider the current and target $25(\mathrm{OH}) \mathrm{D}$ concentrations in the patient's blood [90].

In fact, a considerable number of the experts believe that cancer patients should refrain from any supplementation, especially during chemotherapy and radiation therapy $[66,97,98]$. According to Ambrosone et al. [99], antioxidant supplementation in breast cancer patients undergoing chemotherapy lowered the chance of survival. The American Institute for Cancer Research warned that patients undergoing chemotherapy or radiation should not ingest high doses of vitamins and minerals [100]. Vitamin-mineral preparations are necessary in cases of patient malnutrition. According to the European Society for Clinical Nutrition and Metabolism (ESPEN), cancer patients whose diet provides them with less than $60 \%$ of the required caloric content over the course of at least 1 week, should use vitamin-mineral supplements in adequate doses so that they avoid nutritional deficiencies. However, supplementation should be prescribed and monitored by a physician $[87,88]$. Importantly, more than half of cancer patients declare they received no information whatsoever regarding vitamin and mineral supplementation during therapy [101].

Herbal supplements, which are commonly perceived by patients as completely safe due to their natural origin, are particularly dangerous [102-104]. The risk is associated, among others, with the higher content of active substances in the supplements than occur in the natural herbal resources, which results from the use of concentrated extracts and sometimes additional synthetic analogues $[105,106]$. Additionally, recent years have witnessed the appearance of numerous preparations that include plants that have never previously been used in Western medicine. Their mechanisms of action have not been sufficiently investigated and described, while the labels usually fail to include information about the contraindications, which does not mean they do not exist. Herbal components, especially herbal mixes, may have a negative effect on the drug mechanisms of action, both by accelerating excretion from the body or by producing dangerously high concentrations in the blood [88,104].

The abovementioned data indicate that reasonable supplementation, tailor-made for the cancer patient and supervised by a physician, may in fact bring benefits and constitute a vital element of the cancer treatment. Unsupervised self-administration of dietary supplements may cause serious complications during cancer therapy. Table 2 summarizes the studies included in the paper on the relationships between vitamin-mineral supplementation and cancer.

Table 2. Characteristic of studies evaluating the effect of selected dietary supplements on cancers.

\begin{tabular}{|c|c|c|c|c|c|}
\hline Authors & Study Design & Participants & $\begin{array}{l}\text { Type of Dietary } \\
\text { Supplements }\end{array}$ & $\begin{array}{l}\text { Duration of the } \\
\text { Study }\end{array}$ & Results \\
\hline $\begin{array}{l}\text { Omenn et al., } \\
1996 \text { [80] }\end{array}$ & RCT & 18,314 smokers & $\begin{array}{l}\text { Beta-carotene and } \\
\text { vitamin A }\end{array}$ & Mean: 4 years & $\begin{array}{l}28 \% \text { increase in lung cancer } \\
\text { incidence }\end{array}$ \\
\hline $\begin{array}{l}\text { Albanes et al., } \\
1996 \text { [81] }\end{array}$ & $\mathrm{RCT}$ & $\begin{array}{c}\text { 29,133 smokers aged } \\
50-69 \text { years }\end{array}$ & $\begin{array}{l}\text { Beta-carotene, } \\
\text { vitamin } \mathrm{E}\end{array}$ & Median: 6.1 years & $\begin{array}{l}16 \% \text { increase in lung cancer } \\
\text { incidence with beta-carotene } \\
\text { supplementation; } \\
\text { no effect on lung cancer } \\
\text { incidence with vitamin E } \\
\text { supplementation. }\end{array}$ \\
\hline Lee et al., 2005 [69] & $\mathrm{RCT}$ & $\begin{array}{c}39,876 \text { healthy } \\
\text { women aged } \\
\geq 45 \text { years }\end{array}$ & Vitamin E & Mean: 10.1 years & No effect on cancer incidence \\
\hline $\begin{array}{l}\text { Gaziano et al., } \\
2009 \text { [77] }\end{array}$ & $\mathrm{RCT}$ & $\begin{array}{l}14,641 \text { men aged } \\
\geq 50 \text { years }\end{array}$ & $\begin{array}{c}\text { Vitamin } \mathrm{E} \text {, vitamin } \\
\mathrm{C}\end{array}$ & Mean: 8.0 years & No effect on cancer incidence \\
\hline
\end{tabular}


Table 2. Cont.

\begin{tabular}{|c|c|c|c|c|c|}
\hline Authors & Study Design & Participants & $\begin{array}{l}\text { Type of Dietary } \\
\text { Supplements }\end{array}$ & $\begin{array}{l}\text { Duration of the } \\
\text { Study }\end{array}$ & Results \\
\hline $\begin{array}{l}\text { Klein et al., } \\
2011[78]\end{array}$ & $\mathrm{RCT}$ & $\begin{array}{l}34,887 \text { men aged } \\
\quad \geq 50 \text { years }\end{array}$ & $\begin{array}{l}\text { Vitamin } \mathrm{E}, \\
\text { selenium }\end{array}$ & $7.0-12.0$ years & $\begin{array}{l}17 \% \text { increase in prostate } \\
\text { cancer incidence with vitamin } \\
\text { E supplementation; } \\
\text { no effect on prostate cancer } \\
\text { incidence with selenium } \\
\text { supplementation }\end{array}$ \\
\hline $\begin{array}{l}\text { Park et al., } \\
2011[55]\end{array}$ & Cohort study & $\begin{array}{c}182,099 \text { patients aged } \\
45-75 \text { years }\end{array}$ & Multivitamins & Mean: 11 years & No effect on cancer incidence \\
\hline $\begin{array}{c}\text { Ambrosone et al., } \\
2019 \text { [99] }\end{array}$ & Prospective study & $\begin{array}{l}1134 \text { patients with } \\
\text { breast cancer }\end{array}$ & $\begin{array}{c}\text { Antioxidants, } \\
\text { multivitamins } \\
\text { vitamin B12, iron, }\end{array}$ & 6 months & $\begin{array}{l}41 \% \text { increased risk of } \\
\text { recurrence with antioxidant } \\
\text { supplementation both before } \\
\text { and during chemotherapy; } \\
\text { no effect of multivitamins on } \\
\text { survival outcomes; } \\
\text { 2-fold decrease in the } \\
\text { probability of disease-free } \\
\text { survival for vitamin B12 } \\
\text { supplementation both before } \\
\text { and during chemotherapy; } \\
79 \% \text { higher risk of recurrence } \\
\text { with iron supplementation } \\
\text { both before and during } \\
\text { chemotherapy }\end{array}$ \\
\hline $\begin{array}{l}\text { Narita et al., } \\
2018 \text { [83] }\end{array}$ & Prospective study & 79,705 participants & $\begin{array}{l}\text { Retinol, vitamin } \mathrm{C} \text {, } \\
\text { vitamin } \mathrm{E} \text {, alfa- } \\
\text { carotene, and } \\
\text { beta-carotene }\end{array}$ & Mean: 5 years & $\begin{array}{l}26 \% \text { increase in lung cancer } \\
\text { incidence in men with higher } \\
\text { dietary retinol intake; } \\
\text { no associations with lung } \\
\text { cancer incidence for vitamin } \\
\mathrm{C} \text {, vitamin E, alfa-carotene } \\
\text { and beta-carotene intake }\end{array}$ \\
\hline $\begin{array}{c}\text { Van Gorkom et al., } \\
2019 \text { [96] }\end{array}$ & $\begin{array}{l}\text { A systematic } \\
\text { review, } 19 \text { trials }\end{array}$ & No data & Vitamin C & 1 week-12 months & $\begin{array}{l}\text { No positive effect of vitamin } \\
\text { C supplementation on cancer } \\
\text { patients }\end{array}$ \\
\hline Pais et al., 2013 [85] & $\begin{array}{l}\text { Meta-analysis, } \\
20 \text { RCTs }\end{array}$ & 268,590 participants & Antioxidants & No data & $\begin{array}{c}\text { No effect on colorectal cancer } \\
\text { incidence with antioxidant } \\
\text { supplementation }\end{array}$ \\
\hline $\begin{array}{l}\text { Park et al., } \\
2017 \text { [79] }\end{array}$ & $\begin{array}{l}\text { Meta-analysis, } \\
14 \text { RCTs }\end{array}$ & 147,383 participants & Antioxidants & $1.0-13.0$ years & $\begin{array}{l}\text { No effect on bladder cancer } \\
\text { incidence with antioxidant } \\
\text { supplementation }\end{array}$ \\
\hline $\begin{array}{l}\text { Cortés-Jofré et al., } \\
2020 \text { [84] }\end{array}$ & $\begin{array}{l}\text { Meta-analysis, } \\
12 \text { RCTs }\end{array}$ & $\begin{array}{l}733-212,314 \\
\text { participants } \\
35-84 \text { years }\end{array}$ & Antioxidants & $2.0-12.0$ years & $\begin{array}{l}\text { No beneficial effect on lung } \\
\text { cancer incidence for } \\
\text { combination of vitamins A, C, } \\
\text { E + selenium + zinc } \\
\text { supplementation; } \\
84 \% \text { increase in lung cancer } \\
\text { incidence in women with } \\
\text { vitamin C supplementation; } \\
10 \% \text { increase in lung cancer } \\
\text { incidence in smokers and } \\
\text { people with history of } \\
\text { asbestos exposure with } \\
\text { vitamin A supplementation }\end{array}$ \\
\hline $\begin{array}{l}\text { Bjelakovic et al., } \\
2014 \text { [91] }\end{array}$ & $\begin{array}{l}\text { Meta-analysis, } \\
18 \text { RCTs }\end{array}$ & 50,623 participants & Vitamin D & Mean: 6 years & $\begin{array}{l}\text { No effect on cancer incidence; } \\
12 \% \text { reduction in } \\
\text { cancer death. }\end{array}$ \\
\hline $\begin{array}{l}\text { Goulao et al., } \\
2018 \text { [89] }\end{array}$ & $\begin{array}{l}\text { Meta-analysis, } \\
30 \text { RCTs }\end{array}$ & 18,808 participants & Vitamin D & $\begin{array}{c}\text { Median: } \\
\text { 1,0-6.2 years }\end{array}$ & $\begin{array}{l}\text { No effect on cancer incidence } \\
\text { and mortality }\end{array}$ \\
\hline $\begin{array}{l}\text { Keum et al., } \\
2019 \text { [90] }\end{array}$ & $\begin{array}{l}\text { Meta-analysis, } \\
5-10 \text { RCTs }\end{array}$ & 6537 cases & Vitamin D & $3-10$ years & $\begin{array}{l}\text { No effect on cancer incidence; } \\
13 \% \text { reduction in cancer death }\end{array}$ \\
\hline
\end{tabular}




\subsection{Dietary Supplements and Weight Loss}

The number of people with excessive weight continues to rise, and fighting obesity has become one of the greatest challenges of contemporary medicine. A person wishing to lose weight needs to undertake several difficult life-changes and practice them consistently (diet, physical activity, addiction-free). Meanwhile dietary supplements are presented as a compelling alternative to traditional methods for combatting obesity. Wróbel-Harmas et al. [107] demonstrated that weight loss supplements are the most frequently sought dietary supplements on the Internet, followed by preparations for muscle building and sexual potency. In the US, more than $30 \%$ of people with overweight and obesity believe supplements to be an effective method for losing weight [108], while in Poland these supplements are used by as many as $40-50 \%$ of young women, regardless of their weight [15].

Weight loss supplements are usually multi-ingredient preparations, with over 4000 individual substances used in the production process. The average weight loss supplement available in Western markets is estimated to include 10 different ingredients [109]. The more complex the recipe, the harder it is to determine its effects on the body. The most popular ingredients include chromium and chitosan, as well as green tea, Garcinia cambogia, and bitter orange (Citrus aurantium) extracts $[15,16]$. Over the years, no studies have shown that the use of either single- or multi-ingredient preparations of those substances promotes weight reduction.

A 2013 meta-analysis of randomized studies found that chromium supplementation resulted in only $0.5 \mathrm{~kg}$ additional weight reduction in subjects with overweight and obesity, as compared with those taking a placebo [110], and a comparable result (mean: $0.75 \mathrm{~kg}$ ) was achieved in a similar 2019 meta-analysis [111]. In addition, the literature indicates that chromium supplementation may be associated with several side effects: emesis, nettlerash, and dizziness [112]. Claims about the benefits of chitosan, which allegedly binds to fats in the digestive tract and inhibits fat absorption, are also exaggerated [113,114]. A 2018 meta-analysis of randomized trials revealed that chitosan supplementation for approximately 17 weeks led to a slight decrease in body weight (mean: $1 \mathrm{~kg}$ ) [113], and a similar result was found in a 2020 meta-analysis of similar studies, which reported a 0.89 $\mathrm{kg}$ greater weight loss than those taking a placebo [115]. The effectiveness of green tea extract is also questionable. In light of some data, green tea extract consumed for 12 weeks did not reinforce the weight loss process [116]; in light of other data, consumption of the extract for up to 14 weeks by obese people causes a greater decrease in body weight (by $1.8 \mathrm{~kg}$ ) and BMI (by $0.65 \mathrm{~kg} / \mathrm{m}^{2}$ ) than occurring in those taking a placebo [117]. At the same time, a growing number of studies have shown there is a significant risk linked with green tea extract, and we discuss this in more detail in the Safety of Supplement Use section of the manuscript. Garcinia cambogia, which is a tropical plant whose fruit includes large quantities of hydroxycitric acid, which inhibits appetite and suppresses fatty acid synthesis, has also been advertised by celebrities as a magical aid to losing weight $[104,118,119]$. The results of studies on the effectiveness of Garcinia cambogia in the weight loss process are far from satisfying. A meta-analysis of 2011 randomized controls demonstrated poor-to-borderline statistically significant effects on body weight loss $(-0.88 \mathrm{~kg})$ as compared with those on the placebo and demonstrated no effect on BMI. The authors pointed out the small sample size of the studies they analyzed and the fact that the studies were conducted over short periods of time [120]. Slightly better slimming effects of Garcinia cambogia supplements were shown by a 2020 meta-analysis of such studies, where taking such supplements for 8-12 weeks resulted in decreases in body weight by $-1.34 \mathrm{~kg}$, BMI by $-0.99 \mathrm{~kg} / \mathrm{m}^{2}$, percentage of fat mass by $-0.42 \%$, and waist circumference by $-4.16 \mathrm{~cm}$ compared with the placebo group [121]. Overall, the effectiveness of Garcinia cambogia is believed to be under-researched, and long-term use is not recommended. Additionally, the plant is supposedly hepatotoxic [114,122]. Similarly, results to those above are found in the literature on bitter orange (Citrus aurantium), showing no conclusive proof of its effectiveness $[107,122,123]$. However, there are reports on its serious side effects (hypertension, chest pain, and tachycardia), especially among subjects 
with cardiovascular diseases, as well as indications that it may cause liver damage [124]. The effects of bitter orange alkaloids on liver enzyme activity may also produce negative effects on the efficacy of other medicines [112].

In summarizing current knowledge about weight loss supplements and their effectiveness, it is important to emphasize that none of the available supplements are recommended because their effectiveness is unproven and for safety reasons. Recipients who are exposed to the advertisements of such supplements should be aware that their alleged effectiveness has not been tested in clinical trials. Advertising slogans such as "excellent fat burner" have no grounds. Additionally, if there was a weight loss preparation that was proven to be effective, it would have been registered as a "medicine" and not as a "foodstuff". The two key issues are that these products do not help people lose weight and they have serious side effects, which may be a threat to patient health. Therefore, consuming fat burners, especially those purchased online, has been compared by some authors to playing a game of "Russian roulette" [125]. If, despite the lack of evidence, patients wish to attempt to lose weight using dietary supplements, they should never purchase these products from unauthorized buyers or increase the recommended dose or use several products at the same time in the hope that it would accelerate their weight loss. Various slimming preparations (with different trade names) may contain the same ingredients and their concentration in the body may become dangerously elevated. Table 3 summarizes the studies analyzed in this article on the relationships between dietary supplement use and body weight.

Table 3. Characteristic of studies evaluating the effect of selected dietary supplements on weight loss.

\begin{tabular}{|c|c|c|c|c|c|}
\hline Authors & Study Design & Participants(n) & $\begin{array}{l}\text { Type of Dietary } \\
\text { Supplements }\end{array}$ & $\begin{array}{l}\text { Duration of the } \\
\text { Study }\end{array}$ & Results \\
\hline $\begin{array}{l}\text { Onakpoya et al., } \\
2013 \text { [110] }\end{array}$ & $\begin{array}{c}\text { Meta-analysis, } \\
20 \text { RCTs }\end{array}$ & 1038 & Chromium & 8-26 weeks & $\begin{array}{l}0.5 \mathrm{~kg} \text { more weight loss as } \\
\text { compared with placebo }\end{array}$ \\
\hline $\begin{array}{l}\text { Tsang et al., } 2019 \\
\text { [111] }\end{array}$ & $\begin{array}{l}\text { Meta-analysis, } \\
21 \text { trials }\end{array}$ & 1316 & Chromium & $\leq 12$ weeks & $\begin{array}{l}0.75 \mathrm{~kg} \text { more weight loss } \\
\text { as compared with placebo }\end{array}$ \\
\hline $\begin{array}{l}\text { Moraru et al., } \\
2018 \text { [113] }\end{array}$ & $\begin{array}{l}\text { Meta-analysis, } \\
14 \text { RCTs }\end{array}$ & 1101 & Chitosan & 4-52 weeks & $\begin{array}{l}1.01 \mathrm{~kg} \text { more weight loss } \\
\text { as compared with placebo }\end{array}$ \\
\hline $\begin{array}{l}\text { Huang et al., } \\
2020 \text { [115] }\end{array}$ & $\begin{array}{l}\text { Meta-analysis, } \\
15 \text { RCTs }\end{array}$ & 1130 & Chitosan & $\geq 12$ weeks & $\begin{array}{c}0.89 \mathrm{~kg} \text { more weight loss, } \\
0.39 \mathrm{~kg} / \mathrm{m}^{2} \text { more BMI loss, } \\
\text { and } 0.69 \% \text { more body fat } \\
\text { loss as compared } \\
\text { with placebo }\end{array}$ \\
\hline $\begin{array}{l}\text { Baladia et al., } \\
2014 \text { [116] }\end{array}$ & $\begin{array}{l}\text { Meta-analysis, } \\
5 \text { RCTs }\end{array}$ & 260 & $\begin{array}{l}\text { Green tea, green } \\
\text { tea extract }\end{array}$ & 12 weeks & No effect on body weight \\
\hline $\begin{array}{c}\text { Lin et al., } 2020 \\
\text { [117] }\end{array}$ & $\begin{array}{l}\text { Meta-analysis, } \\
22 \text { RCTs }\end{array}$ & 2357 & Green tea extract & 4-14 weeks & $\begin{array}{c}1.78 \mathrm{~kg} \text { more weight loss } \\
\text { and } 0.65 \mathrm{~kg} / \mathrm{m}^{2} \text { more BMI } \\
\text { loss as compared with } \\
\text { placebo }\end{array}$ \\
\hline $\begin{array}{l}\text { Onakpoya et al., } \\
\text { 2011 [120] }\end{array}$ & $\begin{array}{l}\text { Meta-analysis, } \\
12 \text { RCTs }\end{array}$ & 706 & $\begin{array}{l}\text { hydroxycitric } \\
\text { acid from } \\
\text { Garcinia cambogia }\end{array}$ & 2-12 weeks & $\begin{array}{l}0.88 \mathrm{~kg} \text { more weight loss } \\
\text { as compared with placebo }\end{array}$ \\
\hline $\begin{array}{l}\text { Golzarand et al., } \\
\quad 2020 \text { [121] }\end{array}$ & $\begin{array}{l}\text { Meta-analysis, } \\
8 \text { RCTs }\end{array}$ & 530 & Garcinia cambogia & 8-12 weeks & $\begin{array}{l}1.34 \mathrm{~kg} \text { more weight loss, } \\
0.99 \mathrm{~kg} / \mathrm{m}^{2} \text { more BMI loss, } \\
\text { and } 0.42 \% \text { more body fat } \\
\text { loss, } 4.16 \mathrm{~cm} \text { more loss of } \\
\text { waist circumference as } \\
\text { compared with placebo }\end{array}$ \\
\hline Stohs 2017 [123] & Review 30 trials & 600 & $\begin{array}{c}\text { Citrus aurantium } \\
\text { extract }\end{array}$ & No data & $\begin{array}{l}\text { No proven effect on } \\
\text { body weight }\end{array}$ \\
\hline
\end{tabular}




\subsection{Safety of Supplement Use}

In Europe and the US, no documentation of safety of use is required before the introduction of a dietary supplement to the market, although each jurisdiction's laws clearly state that producers are responsible for the safety of a product [124,126]. Some authors have stated that they believe that supplements are released onto the market to be tested by the end-users [127]. The Food and Drug Administration (FDA) may withdraw a product from the market only after it has been deemed unsafe $[128,129]$. Additionally, routine quality controls are not carried out to check the active substance content and label compliance [105,107], and yet half of some studies' respondents claim that dietary supplements are sufficiently monitored, in the same way that over-the-counter drugs are [107,130].

Evidence of the unfavorable effects of supplement use continues to accumulate. According to the National Estimates of Emergency Department Visits, the most frequent complaints in the US concern herbal or complementary nutritional preparations, including weight loss products ( $66 \%$ and $26 \%$ of all interventions, respectively) [131]. As far as weight loss products are concerned, 13,000 complaints are registered annually, including 2000 hospitalizations [132]. The main side effects include cardiac symptoms (palpitations and chest pains), and the same symptoms have been observed in relation to the use of muscle building and sexual potency supplements [131]. The literature emphasizes that long-term effects of supplement use are difficult to predict and will only be known after they have been present on the market for some years [133]. The Ephedra sinica shrub is an interesting example of this issue, as it became a component of weight loss preparations in the early 1990s in the US and was withdrawn in 2004 due to the incidence of life-threatening cardiac side effects [112]. However, the use of the Ephedra sinica plant in foods, and consequently in dietary supplements, was not banned in the European Union until 2015 [134]. Ephedra herbal supplements accounted for over half of the complaints about adverse reactions to herbs lodged with the US National Estimates of Emergency Department Visits, yet these products constituted only $1 \%$ of total herbal product sales in the US at the time [112]. In 2004, the FDA received over 18,000 complaints and finally ruled that the product should be withdrawn [114]. Sibutramine (active ingredient in medicines) is yet another example of a substance used is weight loss preparations whose negative side effects were revealed only after people had been using it for some time. It was released on the market in the late 1990s as a component of an appetite-blocking drug but was withdrawn in 2010 due to a significant risk of cardiovascular disorders [135].

Since being official banned, both sibutramine and Ephedra sinica have become popular, illegal components of weight loss supplements. In China, significant quantities of sibutramine were detected in 27 out of 120 weight loss supplements [103]. Despite a number of components being listed on the label of one Chinese product, Meizitanc, when investigated in Poland, sibutramine was the only substance in this weight loss [136]. There is also an associated problem of additional ingredients that are also dangerous being included with the banned substances. For instance, the number of reports on laxatives, antidepressant, yohimbine, and even amphetamine and its derivatives being found in supplements continues to grow $[105,106,127,137]$. A US study revealed that 11 out of 21 supplements that contained the Acacia rigidula extract that were purchased on the Internet contained the isomer of amphetamine [138]. In South Korea, substances that bore a structural resemblance to amphetamine were found in 10 out of 110 weight loss supplements [139]. In Italy, 28\% of the supplements purchased online contained sibutramine or substances only permitted in medicines or their analogs, which had not been tested for toxicology [135]. Apart from weight loss supplements, preparations for muscle building and sexual potency have also been found to be contaminated. International studies indicate that $12-58 \%$ of the supplements for physically active people contained substances that have previously been banned by the World Anti-Doping Agency [140].

Despite legal requirements, labels of dietary supplements cannot be treated as a source of reliable information about the products' contents. In North America, where the brain health supplement market is developing rapidly, 10 out of 12 products contained non- 
declarable components, and 8 did not contain at least 1 of the ingredients listed on the label [141]. Overall, it is estimated that approximately $20 \%$ of the supplements contain at least one banned substance. Importantly, in view of the number of products available on the market, the published cases are merely the tip of the iceberg $[105,106]$.

Lack of reliable data on supplement safety, contamination, and adulteration are the reasons why supplements may cause grave side effects. So far, most reports have focused on the green tea extract, which may have caused liver damage, including fatal damage, in more than 50 individuals. For example, Exolise-a weight loss supplement that contained green tea extract—was withdrawn from the market in Spain and France in 2003 [112,129]. Dexaprine was a multi-ingredient supplement with green tea extract that was withdrawn in 2014 in Holland, as even half a tablet resulted in emesis, anxiety, and tachycardia [106]. In Poland, anaphylactic reactions were observed in the case of a multi-ingredient preparation with green tea extract known as Linea Detox [133]. Supplements that contain Garcinia cambogia may also pose a threat to patient life. Two cases are Hydroxycut, which resulted in liver damage, heart arrhythmia, and death [118,124,132]; and Thermatrim, which was suspected of causing toxic leukoencephalopathy [142]. Kratom is yet another example of a dangerous dietary supplement for muscle building that was withdrawn in 2018 from the US market after it caused the death of a young man [128].

The rapid increase in the availability of dietary supplements aimed at improving cognitive function, including Alzheimer's disease, is the reason for the FDA issuing an official statement in 2019 to inform the public that the agency did not investigate dietary supplements for safety and effectiveness and that these preparations may be dangerous, ineffective, and delay patients' decisions to seek medical help [143]. In light of the fact that the disturbing reports we have identified above continue to surface, there is an urgent need for a radical change in the way supplements are introduced to the market $[127,144,145]$, especially in changing perceptions of products from "safe until proven unsafe" to "unsafe until proven safe" [128]. There is a consensus among the experts that supplements require controlled tests to be performed by independent laboratories to check for active substance content and possible adulteration [105-107].

\section{Discussion}

Due to persistent media messaging about poor eating habits and that the typical "Western diet" is far from nutritional, many people are convinced that their daily diet does not meet the recommended levels for vitamins and minerals. However, the scientific literature shows that taking vitamins and minerals without medical justification does not lower the risks of cardiovascular disease and cancer and that sometimes it can even have a negative effect. It should also be borne in mind that disease is influenced by many factors, both genetic and environmental, and a beneficial change in one element of the diet may not have any overall effect. Popular positive expectations of supplements are also dampened by the fact that they are more often used by people who already eat better, lead a healthier lifestyle, are better educated, and have a greater health awareness $[6,8,10]$. Therefore, in such cases where the person already has a better nutritional status, including a lack of vitamin and mineral deficiencies, supplementation may not be of benefit, and longterm consumption of excessive quantities of these nutrients may, in fact, have detrimental side effects. The risk of such side effects increases when consumers take several dietary supplements at the same time (for example, "for immunity", "for the heart", or "for an efficient mind"), as they may contain the same vitamins and minerals as each other.

On the other hand, the beneficial effect of using certain nutrients (omega-3 fatty acids) in the treatment of lipid disorders, as demonstrated in studies, undermines the registration of preparations intended for this purpose as dietary supplements. Dietary supplements, by their definition, serve to supplement the usual diet with nutrients or components with a physiological effect, and this group of preparations does not include medicinal products $[1,2,146]$. Due to one of the basic rules that the use of preparations for therapeutic purposes should be prescribed and under the supervision of a physician, 
"therapeutic" doses of nutrients should not be used in food preparations. Moreover, Polish pharmaceutical law clearly emphasizes that in the case of a product that meets the criteria for classification both as a medicinal product and as a dietary supplement, the provisions of pharmaceutical legislation, rather than food regulations, should be applied [147]. Currently, the dose of active ingredients is an important criterion in the registration process of dietary supplements [148]. It is also worth remembering that labeling and advertising of dietary supplements can neither imply nor make claims about the product's preventive and/or therapeutic properties, which is consistent with food law and the regulations governing all foodstuffs [149]. Therefore, dietary supplement packaging may not contain information such as "for cancer prevention" or "for reducing cholesterol". However, although such requirements have long been in food legislation, the practice of portraying dietary supplements as products that quickly alleviate the symptoms of numerous health conditions, both by labelling and advertising methods, is relatively common [143,150-152]. Unsurprisingly, the public often finds it difficult to differentiate between supplements and drugs $[5,12]$ and uses the former to treat various medical conditions $[128,153,154]$. Such practices have been observed even in the US, where manufacturers are legally obligated to include the information "This product is not intended to diagnose, treat, cure, or prevent any disease" $[9,128]$ on labels, unlike in the European Union. According to various authors, knowledge about supplements among some physicians and pharmacists also leaves much to be desired $[155,156]$. It is worth mentioning here that in Poland, considering the popular misconception that dietary supplements are drugs, as of 1 January 2020, self-regulation of TV broadcasting companies and supplement manufacturers [157] was introduced. The new regulations have introduced several important changes for TV advertising, chief among them the rule that every advertisement is required to include the following statement on screen: "Dietary supplement; contains ingredients which support physiological functions of the body by supplementing a typical diet; has no medicinal properties."

Considering the impact of dietary supplements on people's health, it is important to remember that the results of short-term studies do not provide irrefutable data on their effectiveness and that even long-term studies, where lifestyle factors change over time and influence a person's health, also pose a problem. When interpreting the results of research on intake of vitamin and mineral preparations, especially multivitamin-mineral supplements, it should also be remembered that there is a considerable degree of heterogeneity in supplement ingredients and amounts of nutrients because the composition of supplements is not directly regulated by law. Therefore, individual preparations may significantly differ from each other in dose and composition of ingredients, thus affecting research results. In addition, it should be noted that administering vitamin and mineral supplements to the study group does not mean that the control group did not gain appropriate levels of these ingredients from their daily diets, and thus does not mean that the control group was at risk of hypovitaminosis. Therefore, identifying the potential benefits of supplying nutrients in addition to the body's normal requirements is difficult.

The author of this paper is aware of the limitations and issues in the cited studies and consequently is aware that this is not a systematic review. Therefore, it cannot be ruled out that some publications, possibly presenting different research results, may have been omitted. However, the author has made every effort to include as many publications as possible, including randomized controlled trials and meta-analyses, and to discuss the individual issues in the paper in a balanced way, bearing in mind the length of the paper. Because of the widely different categories of dietary supplements, the article does not address the health effects of all, e.g., probiotics or polyphenols; thus, the author does not present an exhaustive discussion of the health effects resulting from taking supplements.

\section{Conclusions}

In the absence of clinical trials conducted by the manufacturers of dietary supplements prior to their supplements being introduced to the market, being able to understand the health effects of using such preparations is an important public health issue. Most of 
the randomized controlled trials analyzed in this article found that vitamin and mineral supplements do not lower the risk of cardiovascular diseases and cancer, while the role of omega-3 fatty acids in the prevention of cardiological diseases is not conclusively agreed. The use of weight loss supplements is either of marginal benefit or is completely ineffective, while the side effects and the risk of adulteration with illegal substances constitute serious grounds for caution to be advised.

Coming back to the original question in the title of the article, it should be stated that dietary supplements are not recommended for everyone to be used to generally support health and reduce the risk of diseases, but rather to be used by those people with a prolonged nutrient deficiency in their diet or a previously diagnosed deficiency in the body. Therefore, more emphasis should be given to dietary changes, including the benefits of eating more fruits and vegetables, where vitamins and minerals occur naturally in combination with other nutrients that cannot be replicated in food supplements. People who intend to take supplements on their own accord should not choose preparations with the highest nutrient content because, unlike ordinary foods, excessive intake may have serious health consequences.

Funding: This research received no external funding.

Institutional Review Board Statement: Not applicable.

Informed Consent Statement: Not applicable.

Conflicts of Interest: The author declares no conflict of interest.

\section{References}

1. Directive 2002/46/EC of the European Parliament and of the Council of 10 June 2002 on the approximation of the laws of the Member States relating to food supplements. Off. J. Eur. Communities 2002, L 183, 51-57.

2. Dietary Supplement Health and Education Act of 1994. Public Law 103-417. Available online: http://www.fda.gov/opacom/ laws/dshea.html (accessed on 15 December 2020).

3. Chen, F.; Du, M.; Blumberg, J.B.; Chui, K.K.H.; Ruan, M.; Rogers, G.; Shan, Z.; Zeng, L.; Zhang, F.F. Association among dietary supplement use, nutrient intake, and mortality among U.S. adults: A cohort study. Ann. Intern. Med. 2019, 170, 604-613. [CrossRef] [PubMed]

4. Costa, J.G.; Vidovic, B.; Saraiva, N.; Costa, M.D.C.; Del Favero, G.; Marko, D.; Oliveira, N.G.; Fernandes, A.S. Contaminants: A dark side of food supplements? Free. Radic. Res. 2019, 53, 1113-1135. [CrossRef] [PubMed]

5. Wawryk-Gawda, B.; Budzyńska, M.; Lis-Sochocka, P.; Chylińska-Wrzos, M.; Zarobkiewicz, B.; Jodłowska-Jędrych, B. Dietary supplements-Consumer assessment based on questionnaire survey. Przegl. Epidemiol. 2018, 72, 93-103.

6. Waśkiewicz, A.; Sygnowska, E.; Broda, G.; Chwojnowska, Z. The use of vitamin supplements among adults in Warsaw: Is there any nutritional benefit? Rocz. Panstw. Zakl. Hig. 2014, 65, 119-126. [PubMed]

7. Suliga, K.; Grzelak, T.; Grupińska, J.; Pelczyńska, M.; Sperling, M.; Czyżewska, K. Evaluation of using dietary supplements among polish adult people below and over 60 years of age. J. Med. Sci. 2017, 86, 213-219.

8. Sicińska, E.; Pietruszka, B.; Januszko, O.; Kałuża, J. Different Socio-Demographic and Lifestyle Factors Can Determine the Dietary Supplement Use in Children and Adolescents in Central-Eastern Poland. Nutrients 2019, 11, 658. [CrossRef]

9. Ronis, M.J.J.; Pedersen, K.B.; Watt, J. Adverse Effects of Nutraceuticals and Dietary Supplements. Annu. Rev. Pharmacol. Toxicol. 2018, 58, 583-601. [CrossRef]

10. Dickinson, A.; Blatman, J.; El-Dash, N.; Franco, J.C. Consumer Usage and Reasons for Using Dietary Supplements: Report of a Series of Surveys. J. Am. Coll. Nutr. 2014, 33, 176-182. [CrossRef]

11. Karbownik, M.S.; Horne, R.; Paul, E.; Kowalczyk, E.; Szemraj, J. Determinants of knowledge about dietary supplements among Polish Internet users with no medical education: A nationwide cross-sectional study. J. Med. Internet Res. 2021, 23 , e25228. [CrossRef]

12. Wierzejska, R.; Jarosz, M.; Siuba, M.; Rambuszek, M. Assessing patients' attitudes towards dietary supplements. Rocz. Panstw. Zakl. Hig. 2014, 65, 317-323. [PubMed]

13. Schwingshackl, L.; Boeing, H.; Stelmach-Mardas, M.; Gottschald, M.; Dietrich, S.; Hoffmann, G.; Chaimani, A. Dietary Supplements and Risk of Cause-Specific Death, Cardiovascular Disease, and Cancer: A Systematic Review and Meta-Analysis of Primary Prevention Trials. Adv. Nutr. 2017, 8, 27-39. [CrossRef] [PubMed]

14. Hilleman, D.E.; Teply, R.; Packard, K.A. Knowledge, Perceptions, and Patterns of Fish Oil Use in Cardiac Patients. J. Pharm. Pract. 2020, 33, 580-585. [CrossRef] [PubMed]

15. Sadowska, J.; Szuber, M. The estimation of weight-loss programmes and using of slimming preparations among young women. Rocz. Panstw. Zakl. Hig. 2011, 62, 343-350. [PubMed] 
16. Saper, R.B.; Eisenberg, D.M.; Phillips, R.S. Common dietary supplements for weight loss. Am. Fam. Physician 2004, 70, 1731-1738.

17. Innes, J.K.; Calder, P.C. Marine Omega-3 (N-3) Fatty Acids for Cardiovascular Health: An Update for 2020. Int. J. Mol. Sci. 2020, 21, 1362. [CrossRef]

18. Zock, P.L.; Blom, W.A.; Nettleton, J.A.; Hornstra, G. Progressing Insights into the Role of Dietary Fats in the Prevention of Cardiovascular Disease. Curr. Cardiol. Rep. 2016, 18, 1-13. [CrossRef]

19. Zhan, J.; Liu, Y.J.; Cai, L.B.; Xu, F.R.; Xie, T.; He, Q.Q. Fruit and vegetable consumption and risk of cardiovascular disease: A meta-analysis of prospective cohort studies. Crit. Rev. Food Sci. Nutr. 2017, 57, 1650-1663. [CrossRef]

20. Piepoli, M.F.; Abreu, A.; Albus, C.; Ambrosetti, M.; Brotons, C.; Catapano, A.L.; Corra, U.; Cosyns, B.; Deaton, C.; Graham, I.; et al. Update on cardiovascular prevention in clinical practice: A position paper of the European Association of Preventive Cardiology of the European Society of Cardiology. Eur. J. Prev. Cardiol. 2020, 27, 181-205. [CrossRef]

21. Kłosiewicz-Latoszek, L.; Cybulska, B.; Tyszko, P. Current state-of-the-art knowledge on the role of omega-3 fatty acids in the prevention of cardiovascular disease. Ann. Agric. Environ. Med. 2020, 27, 519-525. [CrossRef]

22. The ASCEND Study Collaborative Group. Effects of $\mathrm{n}-3$ fatty acid supplements in diabetes mellitus. N. Engl. J. Med. 2018, 379, 1540-1550. [CrossRef]

23. Manson, J.E.; Cook, N.R.; Lee, I.M.; Christen, W.; Bassuk, S.S.; Mora, S.; Gibson, H.; Albert, C.M.; Gordon, D.; Copeland, T.; et al. VITAL Research Group. Marine n-3 fatty acids and prevention of cardiovascular disease and cancer. N. Engl. J. Med. 2019, 380, 23-32. [CrossRef]

24. Bhatt, D.L.; Steg, P.G.; Miller, M.; Brinton, E.A.; Jacobson, T.A.; Ketchum, S.B.; Doyle, R.T., Jr.; Juliano, R.A.; Jiao, L.; Granowitz, C.; et al. Cardiovascular risk reduction with icosapent ethyl for hypertriglyceridemia. N. Engl. J. Med. 2019, 380, 11-22. [CrossRef] [PubMed]

25. Reddy, K.J.; Chowdhury, S. Improving lipids with prescription icosapent ethyl after previous use of fish oil dietary supplements. Future Cardiol. 2016, 12, 261-268. [CrossRef] [PubMed]

26. Banach, M.; Patti, A.M.; Giglio, R.V.; Cicero, A.F.G.; Atanasov, A.G.; Bajraktari, G.; Bruckert, E.; Descamps, O.; Djuric, D.M.; Ezhov, M.; et al. The role of nutraceuticals in statin intolerant patients. J. Am. Coll. Cardiol. 2018, 72, 96-118. [CrossRef]

27. Nicholls, S.J.; Lincoff, A.M.; Garcia, M.; Bash, D.; Ballantyne, C.M.; Barter, P.J.; Davidson, M.H.; Kastelein, J.J.P.; Koenig, W.; McGuire, D.K.; et al. Effect of high-dose omega-3 fatty acids vs corn oil on major adverse cardiovascular events in patients at high cardiovascular risk: The STRENGTH Randomized Clinical Trial. JAMA 2020, 324, 2268-2280. [CrossRef] [PubMed]

28. Perez-Martinez, P.; Katsiki, N.; Mikhailidis, D.P. The Role of n-3 Fatty Acids in Cardiovascular Disease: Back to the Future. Angiology 2019, 71, 10-16. [CrossRef]

29. Rizos, E.C.; Ntzani, E.E.; Bika, E.; Kostapanos, M.S.; Elisaf, M.S. Association between omega-3 fatty acid supplementation and risk of major cardiovascular disease events: A systematic review and meta-analysis. JAMA 2012, 308, 1024-1033. [CrossRef]

30. Kotwal, S.; Jun, M.; Sullivan, D.; Perkovic, V.; Neal, B. Omega 3 fatty acids and cardiovascular outcomes: Systematic review and meta-analysis. Circ. Cardiovasc. Qual. Outcomes 2012, 5, 808-818. [CrossRef]

31. Kwak, S.M.; Myung, S.K.; Lee, Y.J.; Seo, H.G. Efficacy of omega-3 fatty acid supplements (eicosapentaenoic acid and docosahexaenoic acid) in the secondary prevention of cardiovascular disease: A meta-analysis of randomized, double-blind, placebo-controlled trials. Arch. Intern. Med. 2012, 172, 686-694.

32. Casula, M.; Soranna, D.; Catapano, A.L.; Corrao, G. Long-term effect of high dose omega-3 fatty acid supplementation for secondary prevention of cardiovascular outcomes: A meta-analysis of randomized, double blind, placebo controlled trials. Atheroscler. Suppl. 2013, 14, 243-251. [CrossRef]

33. Wen, Y.; Dai, J.; Gao, Q. Effects of Omega-3 fatty acid on major cardiovascular events and mortality in patients with coronary heart disease: A meta-analysis of randomized controlled trials. Nutr. Metab. Cardiovasc. Dis. 2014, 24, 470-475. [CrossRef] [PubMed]

34. Aung, T.; Halsey, J.; Kromhout, D.; Gerstein, H.C.; Marchioli, R.; Tavazzi, L.; Geleijnse, J.M.; Rauch, B.; Ness, A.; Galan, P.; et al. Associations of omega-3 fatty acid supplement use with cardiovascular disease risks: Meta-analysis of 10 trials involving 77917 individuals. JAMA Cardiol. 2018, 3, 225-234. [CrossRef] [PubMed]

35. Abdelhamid, A.S.; Brown, T.J.; Brainard, J.S.; Biswas, P.; Thorpe, G.C.; Moore, H.J.; Deane, K.H.; AlAbdulghafoor, F.K.; Summerbell, C.D.; Worthington, H.V.; et al. Omega-3 fatty acids for the primary and secondary prevention of cardiovascular disease. Cochrane Database Syst. Rev. 2018, 7, CD003177. [CrossRef]

36. Mazidi, M.; Mikhailidis, D.P.; Banach, M. Omega-3 fatty acids and risk of cardiovascular disease: Systematic review and meta-analysis of randomized controlled trials with 127,447 individuals and a Mendelian randomization study. Circulation 2019, 140, e964-e1011.

37. $\mathrm{Hu}, \mathrm{Y}$; Hu, F.B.; Manson, J.E. Marine Omega-3 Supplementation and Cardiovascular Disease: An Updated Meta-Analysis of 13 Randomized Controlled Trials Involving 127,477 Participants. J. Am. Heart Assoc. 2019, 8, e013543. [CrossRef]

38. Casula, M.; Olmastroni, E.; Gazzotti, M.; Galimberti, F.; Zambon, A.; Catapano, A.L. Omega-3 polyunsaturated fatty acids supplementation and cardiovascular outcomes: Do formulation, dosage, and baseline cardiovascular risk matter? An updated meta-analysis of randomized controlled trials. Pharmacol. Res. 2020, 160, 105060. [CrossRef]

39. Lombardi, M.; Chiabrando, J.G.; Vescovo, G.M.; Bressi, E.; Del Buono, M.G.; Carbone, S.; Koenig, R.A.; Van Tassell, B.W.; Abbate, A.; Biondi-Zoccai, G.; et al. Impact of Different Doses of Omega-3 Fatty Acids on Cardiovascular Outcomes: A Pairwise and Network Meta-analysis. Curr. Atheroscler. Rep. 2020, 22, 1-10. [CrossRef] 
40. Cicero, A.F.G.; Colletti, A.; Bajraktari, G.; Descamps, O.; Djuric, D.M.; Ezhov, M.; Fras, Z.; Katsiki, N.; Langlois, M.; Latkovskis, G.; et al. Lipid lowering nutraceuticals in clinical practice: Position paper from an International Lipid Expert Panel. Arch. Med. Sci. 2017, 13, 965-1005. [CrossRef]

41. Penson, P.E.; Banach, M. Natural compounds as anti-atherogenic agents: Clinical evidence for improved cardiovascular outcomes. Atherosclerosis 2021, 316, 58-65. [CrossRef]

42. Cicero, A.F.G.; Colletti, A.; von Haehling, S.; Vinereanu, D.; Bielecka-Dabrowa, A.; Sahebkar, A.; Toth, P.P.; Reiner, Ž.; Wong, N.D.; Mikhailidis, D.P.; et al. Nutraceutical support in heart failure: A position paper of the International Lipid Expert Panel (ILEP). Nutr. Res. Rev. 2020, 33, 155-179. [CrossRef] [PubMed]

43. Mach, F.; Baigent, C.; Catapano, A.L.; Koskinas, K.C.; Casula, M.; Badimon, L.; Chapman, M.J.; de Backer, G.G.; Delgado, V.; Ference, B.A.; et al., 2019 ESC/EAS Guidelines for the management of dyslipidaemias: Lipid modification to reduce cardiovascular risk. Eur. Heart J. 2020, 41, 111-188. [CrossRef] [PubMed]

44. Arnett, D.K.; Blumenthal, R.S.; Albert, M.A.; Buroker, A.B.; Goldberger, Z.D.; Hahn, E.J.; Himmelfarb, C.D.; Khera, A.; LloydJones, D.; McEvoy, J.W.; et al., 2019 ACC/AHA Guideline on the primary prevention of cardiovascular disease: A report of the American College of Cardiology/American Heart Association Task Force on Clinical Practice Guidelines. Circulation 2019, 140, e596-e646. [CrossRef] [PubMed]

45. Siscovick, D.S.; Barringer, T.A.; Fretts, A.M.; Wu, J.H.Y.; Lichtenstein, A.H.; Costello Rebecca, B.; Kris-Etherton, P.M.; Jacobson, T.A.; Engler, M.B.; Alger, H.M.; et al. Omega-3 polyunsaturated fatty acids (fish oil) supplementation and the prevention of clinical cardiovascular disease. A science advisory from the American Heart Association. Circulation 2017, 135, e867-e884. [CrossRef]

46. Sherratt, S.C.R.; Lero, M.; Mason, R.P. Are dietary fish oil supplements appropriate for dyslipidemia management? A review of the evidence. Curr. Opin. Lipidol. 2020, 31, 94-100. [CrossRef]

47. Hilleman, D.E.; Wiggins, B.S.; Bottorff, M.B. Critical Differences between Dietary Supplement and Prescription Omega-3 Fatty Acids: A Narrative Review. Adv. Ther. 2020, 37, 656-670. [CrossRef]

48. Albert, B.B.; Derraik, J.; Cameron-Smith, D.; Hofman, P.L.; Tumanov, S.; Villas-Boas, S.; Garg, M.L.; Cutfield, W.S. Fish oil supplements in New Zealand are highly oxidised and do not meet label content of n-3 PUFA. Sci. Rep. 2015, 5, srep07928. [CrossRef]

49. Hilleman, D.; Smer, A. Prescription Omega-3 Fatty Acid Products and Dietary Supplements Are Not Interchangeable. Manag. Care 2016, 25, 46-52.

50. Rautiainen, S.; Wang, L.; Lee, I.-M.; Manson, J.E.; Gaziano, J.M.; Buring, J.E.; Sesso, H.D. Multivitamin use and the risk of hypertension in a prospective cohort study of women. J. Hypertens. 2016, 34, 1513-1519. [CrossRef]

51. Wang, C.; Li, Y.; Zhu, K.; Dong, Y.-M.; Sun, C.-H. Effects of supplementation with multivitamin and mineral on blood pressure and C-reactive protein in obese Chinese women with increased cardiovascular disease risk. Asia Pac. J. Clin. Nutr. 2009, 18, 121-130.

52. Li, K.; Liu, C.; Kuang, X.; Deng, Q.; Zhao, F.; Li, D. Effects of Multivitamin and Multimineral Supplementation on Blood Pressure: A Meta-Analysis of 12 Randomized Controlled Trials. Nutrients 2018, 10, 1018. [CrossRef]

53. Poorolajal, J.; Zeraati, F.; Soltanian, A.R.; Sheikh, V.; Hooshmand, E.; Maleki, A. Oral potassium supplementation for management of essential hypertension: A meta-analysis of randomized controlled trials. PLoS ONE 2017, 12, e0174967. [CrossRef]

54. Filippini, T.; Naska, A.; Kasdagli, M.; Torres, D.; Lopes, C.; Carvalho, C.; Moreira, P.; Malavolti, M.; Orsini, N.; Whelton, P.K.; et al. Potassium Intake and Blood Pressure: A Dose-Response Meta-Analysis of Randomized Controlled Trials. J. Am. Heart Assoc. 2020, 9, e015719. [CrossRef]

55. Park, S.-Y.; Murphy, S.P.; Wilkens, L.R.; Henderson, B.E.; Kolonel, L.N. Multivitamin Use and the Risk of Mortality and Cancer Incidence: The Multiethnic Cohort Study. Am. J. Epidemiol. 2011, 173, 906-914. [CrossRef]

56. Sesso, H.D.; Christen, W.G.; Bubes, V.; Smith, J.P.; MacFadyen, J.; Schvartz, M.; Manson, J.E.; Glynn, R.J.; Buring, J.E.; Gaziano, J.M. Multivitamins in the prevention of cardiovascular disease in men: The Physicians' Health Study II randomized controlled trial. JAMA 2012, 308, 1751-1760. [CrossRef]

57. Albert, C.M.; Cook, N.R.; Gaziano, J.M.; Zaharris, E.; MacFadyen, J.; Danielson, E.; Buring, J.E.; Manson, J.E. Effect of folic acid and B-vitamins on risk of cardiovascular events and total mortality among women at high risk for cardiovascular disease: A randomized trial. JAMA 2008, 17, 2027-2036. [CrossRef]

58. Galan, P.; Kesse-Guyot, E.; Czernichow, S.; Briancon, S.; Blacher, J.; Hercberg, S. Effects of B vitamins and omega 3 fatty acids on cardiovascular diseases: A randomised placebo controlled trial. BMJ 2010, 341, c6273. [CrossRef]

59. Huo, Y.; Li, J.; Qin, X.; Huang, Y.; Wang, X.; Gottesman, R.F.; Tang, G.; Wang, B.; Chen, D.; He, M.; et al. Efficacy of folic acid therapy in primary prevention of stroke among adults with hypertension in China: The CSPPT randomized clinical trial. JAMA 2015, 13, 1325-1335. [CrossRef] [PubMed]

60. Kim, J.; Choi, J.; Kwon, S.Y.; McEvoy, J.W.; Blaha, M.J.; Blumenthal, R.S.; Guallar, E.; Zhao, D.; Michos, E.D. Association of multivitamin and mineral supplementation and risk of cardiovascular disease. A systematic review and meta-analysis. Circ. Cardiovasc. Qual. Outcomes 2018, 11, e004224. [CrossRef]

61. Khan, S.U.; Khan, M.U.; Riaz, H.; Valavoor, S.; Zhao, D.; Vaughan, L.; Okunrintemi, V.; Riaz, I.B.; Khan, M.S.; Kaluski, E.; et al. Effects of nutritional supplements and dietary interventions on cardiovascular outcomes: An umbrella review and evidence map. Ann. Intern. Med. 2019, 171, 190-198. [CrossRef] 
62. Fortmann, S.P.; Burda, B.U.; Senger, C.A.; Lin, J.S.; Whitlock, E.P. Vitamin, mineral, and multivitamin supplements for the primary prevention of cardiovascular disease and cancer: A systematic evidence review for the U.S. Preventive Services Task Force. Ann. Intern. Med. 2013, 159, 824-834. [CrossRef]

63. Sunkara, A.; Raizner, A. Supplemental Vitamins and Minerals for Cardiovascular Disease Prevention and Treatment. Methodist Debakey Cardiovasc. J. 2019, 15, 179-184. [PubMed]

64. Franco, R.; Casanovas, B.; Camps, J.; Navarro, G.; Martínez-Pinilla, E. Antioxidant supplements versus health benefits of brief/intermittent exposure to potentially toxic physical or chemical agents. Curr. Issues Mol. Biol. 2021, 43, 650-664. [CrossRef] [PubMed]

65. Sharifi-Rad, M.; Anil Kumar, N.A.; Zucca, P.; Varoni, E.M.; Dini, L.; Panzarini, E.; Rajkovic, J.; Tsouh Fokou, P.V.; Azzini, E.; Peluso, I.; et al. Lifestyle, Oxidative Stress, and Antioxidants: Back and Forth in the Pathophysiology of Chronic Diseases. Front. Physiol. 2020, 11, 694. [CrossRef]

66. Mandecka, A.; Czekajło, A.; Madalińska, M.; Różańska, D.; Kłaniewski, T.; Szuba, A.; Regulska-Ilow, B. The use of antioxidant vitamin supplements among oncological patients. Adv. Clin. Exp. Med. 2018, 27, 1365-1369. [CrossRef] [PubMed]

67. Patti, A.M.; Al-Rasadi, K.; Giglio, R.V.; Nikolic, D.; Mannina, C.; Castellino, G.; Chianetta, R.; Banach, M.; Cicero, A.F.; Lippi, G.; et al. Natural approaches in metabolic syndrome management. Arch. Med. Sci. 2018, 14, 422-441. [CrossRef] [PubMed]

68. Momtazi-Borojeni, A.; Katsiki, N.; Pirro, M.; Banach, M.; Rasadi, K.A.; Sahebkar, A. Dietary natural products as emerging lipoprotein(a)-lowering agents. J. Cell. Physiol. 2019, 234, 12581-12594. [CrossRef]

69. Lee, I.-M.; Cook, N.; Gaziano, J. Vitamin E in the Primary Prevention of Cardiovascular Disease and Cancer. The Women's Health Study: A Randomized Controlled Trial. ACC Curr. J. Rev. 2005, 14, 10-11. [CrossRef]

70. Lonn, E.; Bosch, J.; Yusuf, S.; Sheridan, P.; Pogue, J.; Arnold, J.M.O.; Ross, C.; Arnold, A.; Sleight, P.; Probstfield, J.; et al. Effects of long-term vitamin E supplementation on cardiovascular events and cancer: A randomized controlled trial. JAMA 2005, 293, 1338-1347.

71. Wang, T.; Xu, L. Circulating Vitamin E Levels and Risk of Coronary Artery Disease and Myocardial Infarction: A Mendelian Randomization Study. Nutrients 2019, 11, 2153. [CrossRef]

72. Vivekananthan, D.P.; Penn, M.S.; Sapp, S.K.; Hsu, A.; Topol, E.J. Use of antioxidant vitamins for the prevention of cardiovascular disease: Meta-analysis of randomised trials. Lancet 2003, 361, 2017-2023. [CrossRef]

73. Loffredo, L.; Perri, L.; Di Castelnuovo, A.; Iacoviello, L.; De Gaetano, G.; Violi, F. Supplementation with vitamin E alone is associated with reduced myocardial infarction: A meta-analysis. Nutr. Metab. Cardiovasc. Dis. 2015, 25, 354-363. [CrossRef]

74. Moyer, V.A.; U.S. Preventive Services Task Force. Vitamin, mineral, and multivitamin supplements for the primary prevention of cardiovascular disease and cancer: U.S. Preventive services Task Force recommendation statement. Ann. Intern. Med. 2014, 160, 558-564. [CrossRef]

75. Guallar, E.; Stranges, S.; Mulrow, C.; Appel, L.J.; Miller, E.R. Enough Is Enough: Stop Wasting Money on Vitamin and Mineral Supplements. Ann. Intern. Med. 2013, 159, 850-851. [CrossRef]

76. Vernieri, C.; Nichetti, F.; Raimondi, A.; Pusceddu, S.; Platania, M.; Berrino, F.; de Braud, F. Diet and supplements in cancer prevention and treatment: Clinical evidences and future perspectives. Crit. Rev. Oncol. Hematol. 2018, 123, 57-73. [CrossRef]

77. Gaziano, J.M.; Glynn, R.J.; Christen, W.G.; Kurth, T.; Belanger, C.; MacFadyen, J.; Bubes, V.; Manson, J.E.; Sesso, H.D.; Buring, J.E. Vitamins $\mathrm{E}$ and $\mathrm{C}$ in the prevention of prostate and total cancer in men: The Physicians' Health Study II randomized controlled trial. JAMA 2009, 301, 52-62. [CrossRef]

78. Klein, E.A.; Thompson, I.; Tangen, C.M.; Lucia, M.S.; Goodman, P.; Minasian, L.M.; Ford, L.G.; Parnes, H.L.; Gaziano, J.M.; Karp, D.D.; et al. Vitamin E and the risk of prostate cancer: The Selenium and Vitamin E Cancer Prevention Trial (SELECT). J. Clin. Oncol. 2012, 30, 7. [CrossRef]

79. Park, S.J.; Myung, S.K.; Lee, Y.; Lee, Y.J. Effects of vitamin and antioxidant supplements in prevention of bladder cancer: A meta-analysis of randomized controlled trials. J. Korean Med. Sci. 2017, 32, 628-635. [CrossRef]

80. Omenn, G.S.; Goodman, G.E.; Thornquist, M.D.; Balmes, J.; Cullen, M.R.; Glass, A.; Keogh, J.P.; Meyskens, F.L.; Valanis, B.; Williams, J.H.; et al. Effects of a Combination of Beta Carotene and Vitamin A on Lung Cancer and Cardiovascular Disease. N. Engl. J. Med. 1996, 334, 1150-1155. [CrossRef]

81. Albanes, D.; Heinonen, O.P.; Taylor, P.R.; Virtamo, J.; Edwards, B.K.; Rautalahti, M.; Hartman, A.M.; Palmgren, J.; Freedman, L.S.; Haapakoski, J.; et al. Alpha-tocopherol and beta-carotene supplements and lung cancer incidence in the alpha-tocopherol, beta-carotene cancer prevention study: Effects of base-line characteristics and study compliance. J. Natl. Cancer Ins. 1996, 88, 1560-1570. [CrossRef]

82. Middha, P.; Weinstein, S.J.; Männistö, S.; Albanes, D.; Mondul, A.M. $\beta$-carotene supplementation and lung cancer incidence in the alpha-tocopherol, beta-carotene cancer prevention study: The role of tar and nicotine. Nicotine Tob. Res. 2019, 21, 1045-1050. [CrossRef]

83. Narita, S.; Saito, E.; Sawada, N.; Shimazu, T.; Yamaji, T.; Iwasaki, M.; Ishihara, J.; Takachi, R.; Shibuya, K.; Inoue, M.; et al. Dietary consumption of antioxidant vitamins and subsequent lung cancer risk: The Japan Public Health Center-based prospective study. Int. J. Cancer 2018, 142, 2441-2460. [CrossRef]

84. Cortés-Jofré, M.; Rueda, J.-R.; Asenjo-Lobos, C.; Madrid, E.; Cosp, X.B. Drugs for preventing lung cancer in healthy people. Cochrane Database Syst. Rev. 2020, 2020, CD002141. [CrossRef]

85. Pais, R.; Dumitraşcu, D.L. Do antioxidants prevent colorectal cancer? A meta-analysis. Rom. J. Intern. Med. 2013, 51, 152-163. 
86. Hercberg, S.; Czernichow, S.; Galan, P. Antioxidant vitamins and minerals in prevention of cancers: Lessons from the SU.VI.MAX study. Br. J. Nutr. 2006, 96, S28-S30. [CrossRef]

87. Harvie, M. Nutritional Supplements and Cancer: Potential Benefits and Proven Harms. Am. Soc. Clin. Oncol. Educ. Book 2014, e478-e486. [CrossRef]

88. Gröber, U.; Holzhauer, P.; Kisters, K.; Holick, M.F.; Adamietz, I.A. Micronutrients in Oncological Intervention. Nutrients 2016, 8, 163. [CrossRef]

89. Goulão, B.; Stewart, F.; Ford, J.; MacLennan, G.; Avenell, A. Cancer and vitamin D supplementation: A systematic review and meta-analysis. Am. J. Clin. Nutr. 2018, 107, 652-663. [CrossRef]

90. Keum, N.; Lee, D.H.; Greenwood, D.C.; Manson, E.; Giovannucci, E. Vitamin D supplementation and total cancer incidence and mortality: A meta-analysis of randomized controlled trials. Ann. Oncol. 2019, 30, 733-743. [CrossRef]

91. Bjelakovic, G.; Gluud, L.L.; Nikolova, D.; Whitfield, K.; Krstic, G.; Wetterslev, J.; Gluud, C. Vitamin D supplementation for prevention of cancer in adults. Cochrane Database Syst. Rev. 2014, 23, CD007469. [CrossRef]

92. Shams-White, M.M.; Brockton, P.; Mitrou, D.; Romaguera, D.; Brown, S.; Bender, A.; Kahle, L.L.; Reedy, J. Operationalizing the 2018 world Cancer research Fund/American institute for Cancer research (WCRF/AICR) Cancer prevention recommendations: A standardized scoring system. Nutrients 2019, 11, 1572. [CrossRef]

93. Poljsak, B.; Milisav, I. The Role of Antioxidants in Cancer, Friends or Foes? Curr. Pharm. Des. 2019, 24, 5234-5244. [CrossRef]

94. Velicer, C.M.; Ulrich, C.M. Vitamin and mineral supplement use among US adults after cancer diagnosis: A systematic review. J. Clin. Oncol. 2008, 26, 665-673. [CrossRef]

95. Ostrander, G.K.; Cheng, K.; Wolf, J.C.; Wolfe, M.J. Shark Cartilage, Cancer and the Growing Threat of Pseudoscience. Cancer Res. 2004, 64, 8485-8491. [CrossRef]

96. Van Gorkom, G.N.; Lookermans, E.L.; Van Elssen, C.H.; Bos, G.M. The Effect of Vitamin C (Ascorbic Acid) in the Treatment of Patients with Cancer: A Systematic Review. Nutrients 2019, 11, 977. [CrossRef]

97. Kamian, S.; Mafi, A.R.Z. Use of Dietary Supplements in Cancer: A Single-Institution Study. Rep. Radiother. Oncol. 2019, 5, e79566. [CrossRef]

98. Smith, R.E. The Effects of Dietary Supplements that Overactivate the Nrf2/ARE System. Curr. Med. Chem. 2020, 27, 2077-2094. [CrossRef]

99. Ambrosone, C.B.; Zirpoli, G.R.; Hutson, A.D.; McCann, W.E.; McCann, S.E.; Barlow, W.E.; Kelly, K.M.; Cannioto, R.; Sucheston-Campbell, L.E.; Hershman, D.L.; et al. Dietary supplement use during chemotherapy and survival outcomes of patients with breast cancer enrolled in a Cooperative Group Clinical Trial (SWOG S0221). J. Clin. Oncol. 2020, 38, 804-814. [CrossRef]

100. Norman, H.A.; Butrum, R.R.; Feldman, E.; Heber, D.; Nixon, D.; Picciano, M.F.; Rivlin, R.; Simopoulos, A.; Wargovich, M.J.; Weisburger, E.K.; et al. The role of dietary supplements during cancer therapy. J. Nutr. 2003, 133, 3794-3799. [CrossRef]

101. Zirpoli, G.R.; Brennan, P.; Hong, C.-C.; McCann, S.E.; Ciupak, G.; Davis, W.; Unger, J.M.; Budd, G.T.; Hershman, D.L.; Moore, H.C.; et al. Supplement use during an intergroup clinical trial for breast cancer (S0221). Breast Cancer Res. Treat. 2013, 137, 903-913. [CrossRef]

102. Xing, S.; Sharp, L.; Touchette, D. Weight loss drugs and lifestyle modification: Perceptions among a diverse adult sample. Patient Educ. Couns. 2017, 100, 592-597. [CrossRef]

103. Cheng, Q.; Shou, L.; Chen, C.; Shi, S.; Zhou, M. Application of ultra-high-performance liquid chromatography coupled with LTQ-Orbitrap mass spectrometry for identification, confirmation and quantitation of illegal adulterated weight-loss drugs in plant dietary supplements. J. Chromatogr. B 2017, 1064, 92-99. [CrossRef] [PubMed]

104. Semwal, R.B.; Semwal, D.; Vermaak, I.; Viljoen, A. A comprehensive scientific overview of Garcinia cambogia. Fitoterapia 2015, 102, 134-148. [CrossRef]

105. White, C.M. Dietary Supplements Pose Real Dangers to Patients. Ann. Pharmacother. 2020, 54, 815-819. [CrossRef]

106. Končić, M.Z. Getting More Than You Paid For: Unauthorized "Natural” Substances in Herbal Food Supplements on EU Market. Planta Med. 2018, 84, 394-406. [CrossRef]

107. Wróbel-Harmas, M.; Krysińska, M.; Postupolski, J.; Wysocki, M.J. Food supplement-related risks in the light of internet and RASFF data. Prz. Epidemiol. 2014, 68, 613-619.

108. Manore, M.M. Dietary Supplements for Improving Body Composition and Reducing Body Weight: Where Is the Evidence? Int. J. Sport Nutr. Exerc. Metab. 2012, 22, 139-154. [CrossRef]

109. Sharpe, P.A.; Granner, M.L.; Conway, J.M.; Ainsworth, B.E.; Dobre, M. Availability of Weight-Loss Supplements: Results of an Audit of Retail Outlets in a Southeastern City. J. Am. Diet. Assoc. 2006, 106, 2045-2051. [CrossRef] [PubMed]

110. Onakpoya, I.; Posadzki, P.; Ernst, E. Chromium supplementation in overweight and obesity: A systematic review and metaanalysis of randomized clinical trials. Obes. Rev. 2013, 14, 496-507. [CrossRef]

111. Tsang, C.; Taghizadeh, M.; Aghabagheri, E.; Asemi, Z.; Jafarnejad, S. A meta-analysis of the effect of chromium supplementation on anthropometric indices of subjects with overweight or obesity. Clin. Obes. 2019, 9, e12313. [CrossRef]

112. Wharton, S.; Bonder, R.; Jeffery, A.; Christensen, R.A.G. The safety and effectiveness of commonly-marketed natural supplements for weight loss in populations with obesity: A critical review of the literature from 2006 to 2016. Crit. Rev. Food Sci. Nutr. 2019, 60, 1614-1630. [CrossRef] [PubMed] 
113. Moraru, C.; Mincea, M.M.; Frandes, M.; Timar, B.; Ostafe, V. A Meta-Analysis on Randomised Controlled Clinical Trials Evaluating the Effect of the Dietary Supplement Chitosan on Weight Loss, Lipid Parameters and Blood Pressure. Medicina 2018, 54, 109. [CrossRef]

114. Esteghamati, A.; Mazaheri, T.; Rad, M.V.; Noshad, S. Complementary and Alternative Medicine for the Treatment of Obesity: A Critical Review. Int. J. Endocrinol. Metab. 2015, 13, e19678. [CrossRef]

115. Huang, H.; Liao, D.; Zou, Y.; Chi, H. The effects of chitosan supplementation on body weight and body composition: A systematic review and meta-analysis of randomized controlled trials. Crit. Rev. Food Sci. Nutr. 2019, 60, 1815-1825. [CrossRef]

116. Baladia, E.; Basulto, J.; Manera, M.; Martínez, R.; Calbet, D. Effect of green tea or green tea extract consumption on body weight and body composition; systematic review and meta-analysis. Nutr. Hosp. 2014, 29, 479-490. [PubMed]

117. Lin, Y.; Shi, D.; Su, B.; Wei, J.; Găman, M.-A.; Macit, M.S.; Nascimento, I.J.B.D.; Guimaraes, N.S. The effect of green tea supplementation on obesity: A systematic review and dose-response meta-analysis of randomized controlled trials. Phytother. Res. 2020, 34, 2459-2470. [CrossRef] [PubMed]

118. Lunsford, K.E.; Bodzin, A.S.; Reino, D.C.; Wang, H.L.; Busuttil, R.W. Dangerous dietary supplements: Garcinia cambogiaassociated hepatic failure requiring transplantation. World J. Gastroenter. 2016, 22, 10071-10076. [CrossRef]

119. Willoughby, D.; Hewlings, S.; Kalman, D. Body Composition Changes in Weight Loss: Strategies and Supplementation for Maintaining Lean Body Mass, a Brief Review. Nutrients 2018, 10, 1876. [CrossRef]

120. Onakpoya, I.; Hung, S.K.; Perry, R.; Wider, B.; Ernst, E. The Use of Garcinia Extract (Hydroxycitric Acid) as a Weight loss Supplement: A Systematic Review and Meta-Analysis of Randomised Clinical Trials. J. Obes. 2010, 2011, 509038. [CrossRef]

121. Golzarand, M.; Omidian, M.; Toolabi, K. Effect of Garcinia cambogia supplement on obesity indices: A systematic review and dose-response meta-analysis. Complement. Ther. Med. 2020, 52, 102451. [CrossRef]

122. Ríos-Hoyo, A.; Gutiérrez-Salmeán, G. New Dietary Supplements for Obesity: What We Currently Know. Curr. Obes. Rep. 2016, 5, 262-270. [CrossRef]

123. Stohs, S.J. Safety, efficacy, and mechanistic studies regarding Citrus aurantium (bitter orange) extract and p-Synephrine. Phytother. Res. 2017, 3, 1463-1474. [CrossRef]

124. Crescioli, G.; Lombardi, N.; Bettiol, A.; Marconi, E.; Risaliti, F.; Bertoni, M.; Ippolito, F.M.; Maggini, V.; Gallo, E.; Firenzuoli, F.; et al. Acute liver injury following Garcinia cambogia weight-loss supplementation: Case series and literature review. Intern. Emerg. Med. 2018, 13, 857-872. [CrossRef]

125. Petróczi, A.; Ocampo, J.A.V.; Shah, I.; Jenkinson, C.M.C.; New, R.; James, R.A.; Taylor, G.; Naughton, D.P. Russian roulette with unlicensed fat-burner drug 2,4-dinitrophenol (DNP): Evidence from a multidisciplinary study of the internet, bodybuilding supplements and DNP users. Subst. Abus. Treat. Prev. Policy 2015, 10, 39. [CrossRef]

126. Santini, A.; Cammarata, S.M.; Capone, G.; Ianaro, A.; Tenore, G.C.; Pani, L.; Novellino, E. Nutraceuticals: Opening the debate for a regulatory framework. Br. J. Clin. Pharmacol. 2018, 84, 659-672. [CrossRef] [PubMed]

127. Makowska, M.; Jasiński, Ł. A discussion of the unresolved 2016/17 plans for regulating the Polish dietary supplements market. Health Policy 2019, 123, 544-549. [CrossRef] [PubMed]

128. Kennett, G. Time for change: Stepping up the FDA's regulation of dietary supplements to promote consumer safety and awareness. J. Law Health 2019, 33, 47-78.

129. Liver Tox. Clinical and Research Information on Drug-Induced Injury. Green Tea. National Institute of Diabetes and Digestive and Kidney Diseases; 2018. Available online: https://www.ncbi.nlm.nih.gov/books/ (accessed on 7 December 2020).

130. Pillitteri, J.L.; Shiffman, S.; Rohay, J.M.; Harkins, A.M.; Burton, S.L.; Wadden, T.A. Use of Dietary Supplements for Weight Loss in the United States: Results of a National Survey. Obesity 2008, 16, 790-796. [CrossRef] [PubMed]

131. Geller, A.I.; Shehab, N.; Weidle, N.J.; Lovegrove, M.C.; Wolpert, B.J.; Timbo, B.B.; Mozersky, R.P.; Budnitz, D.S. Emergency department visits for adverse events related to dietary supplements. N. Engl. J. Med. 2015, 337, 1531-1540. [CrossRef] [PubMed]

132. Inayat, F.; Majeed, C.N.; Ali, N.S.; Hayat, M.; Vasim, I. The risky side of weight-loss dietary supplements: Disrupting arrhythmias causing sudden cardiac arrest. BMJ Case Rep. 2018, 11, e227531. [CrossRef]

133. Flis, P.; Mehrholz, D.; Nowicki, R.; Barańska-Rybak, W. Slim figure for high price. Urticaria due to weight loss products and performance enhancers-A review of three cases. Med. Ogólna Nauk. Zdrowiu 2015, 21, 369-371. [CrossRef]

134. Regulation (EC) No 1925/2006 of the European Parliament and of the Council of 20 December 2006 on the addition of vitamins and minerals and of certain other substances to foods. Off. J. Eur. Union 2006, L 404, 26-38.

135. Gaudiano, M.C.; Manna, L.; Bartolomei, M.; Rodomonte, A.L.; Bertocchi, P.; Antoniella, E.; Romanini, L.; Alimonti, S.; Rufini, L.; Valvo, L. Health risks related to illegal and on-line sale of drugs and food supplements: Results of a survey on marketed products in Italy from 2011 to 2013. Ann. Ist. Super Sanita 2016, 52, 128-132.

136. Wiergowski, M.; Galer-Tatarowicz, K.; Nowak-Banasik, L.; Rutkowska, J.; Kucułyma, G.; Waldman, W.; Chodorowski, Z.; Jankowski, Z.; Anand, J.S. Hazard for human health and life by unintentional use of synthetic sibutramine, which was sold as Chinese herbal product "meizitanc". Prz. Lek. 2007, 64, 268-272.

137. Łukasik-Grębocka, M.; Sommerfeld, K.; Teżyk, A.; Zielńska-Psuja, B. Acute poisoning with weight-loss dietary supplement falsely suggesting the use of amphetamine. Prz. Lek. 2013, 70, 1-4.

138. Cohen, P.A.; Bloszies, C.; Yee, C.; Gerona, R. An amphetamine isomer whose efficacy and safety in humans has never been studied, $\beta$-methylphenylethylamine (BMPEA), is found in multiple dietary supplements. Drug Test. Anal. 2015, 8, 328-333. [CrossRef] 
139. Yun, J.; Kwon, K.; Choi, J.; Jo, C.-H. Monitoring of the amphetamine-like substances in dietary supplements by LC-PDA and LC-MS/MS. Food Sci. Biotechnol. 2017, 26, 1185-1190. [CrossRef]

140. Helle, C.; Sommer, A.K.; Syversen, P.V.; Lauritzen, F. Doping substances in dietary supplements. Tidsskr. Nor. Legeforening 2019, 139. [CrossRef]

141. Crawford, C.; Saldanha, L.; Costello, R.; Deuster, P.A. Dietary Supplements for Musculoskeletal Pain: Science Versus Claims. J. Spéc. Oper. Med. 2018, 18, 110-114.

142. Escamilla-Ocañas, C.E.; Cantú-Martinez, L.; Martínez, H.R.; Cámara-Lemarroy, C.R. Acute toxic leukoencephalopathy associated with a non-prescription weight loss supplement: A report of two cases. Neurol. Sci. 2017, 38, 2199-2201. [CrossRef]

143. Crawford, C. A public health issue: Dietary supplements promoted for brain health and cognitive performance. J. Altern. Complement. Med. 2020, 26, 265-272. [CrossRef]

144. Cohen, P.A.; Bass, S. Injecting Safety into Supplements-Modernizing the Dietary Supplement Law. N. Engl. J. Med. 2019, 381, 2387-2389. [CrossRef] [PubMed]

145. Czepielewska, E.; Makarewicz-Wujec, M.; Różewski, F.; Wojtasik, E.; Kozłowska-Wojciechowska, M. Drug adulteration of food supplements: A threat to public health in the European Union? Regul. Toxicol. Pharmacol. 2018, 97, 98-102. [CrossRef]

146. Act of 25 August 2006 on food and nutrition safety. Pol. J. Laws 2006, 171, 14365-14378, as amended.

147. Act of 6 September 2001 Pharmaceutical Law. Pol. J. Laws 2001, 126, 9811-9844, as amended.

148. Chief Sanitary Inspectorate. Available online: https:/ / www.gis.gov.pl (accessed on 12 January 2021).

149. Regulation (EU) no 1169/2011 of the European Parliament and of the Council of 25 October 2011 on the provision of food information to consumers. Off. J. Eur. Union 2011, L 304, 18-63.

150. Koo, K.; Aro, T.; Matlaga, B.R. Buyer Beware: Evidence-Based Evaluation of Dietary Supplements for Nephrolithiasis. J. Endourol. 2020, 34, 702-707. [CrossRef]

151. Lee, A.; Vásquez, L.J.; Wong, W.C.; Shin, J. Evaluation of dietary supplement advertisements in popular Spanish, Chinese, and Korean media outlets: A cross sectional study. BMC Nutr. 2015, 1, 43. [CrossRef]

152. Wierzejska, R. Whether the advertisement of dietary supplements is objective source of data about their impact on health? Analysis of broadcasting advertisements in the terms of the food law. Wiad. Lek. 2016, 69, 14-18.

153. Sirico, F.; Miressi, S.; Castaldo, C.; Spera, R.; Montagnani, S.; Di Meglio, F.; Nurzynska, D. Habits and beliefs related to food supplements: Results of a survey among Italian students of different education fields and levels. PLoS ONE 2018, 13, e0191424. [CrossRef]

154. Blendon, R.J.; Benson, J.M.; Botta, M.D.; Weldon, K.J. Users' Views of Dietary Supplements. JAMA Intern. Med. 2013, 173, 74-76. [CrossRef] [PubMed]

155. Waddington, F.; Naunton, M.; Kyle, G.; Thomas, J.; Cooper, G.; Waddington, A. A systematic review of community pharmacist therapeutic knowledge of dietary supplements. Int. J. Clin. Pharm. 2015, 37, 439-446. [CrossRef] [PubMed]

156. Cellini, M.; Attipoe, S.; Seales, P.; Gray, R.; Ward, A.; Stephens, M.; Deuster, P.A. Dietary supplements: Physician knowledge and adverse event reporting. Med. Sci. Sports Exerc. 2013, 45, 23-28. [CrossRef] [PubMed]

157. National Broadcasting Council (Krajowa Rada Radiofonii i Telewizji). Available online: http://www.krrit.gov.pl/Data/Files/ _public/Portals / 0/samoregulacja-nadawcow/porozumienie-nadawcow---skan.pdf (accessed on 6 September 2020). 